\title{
A zsámbéki Strázsa-hegy és környékének kainozoos képződményei
}

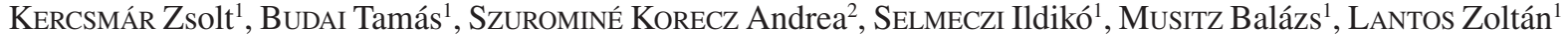

\author{
${ }^{1}$ Magyar Bányászati és Földtani Szolgálat, 1143 Budapest, Stefánia út 14. \\ ${ }^{2}$ Laboratóriumok MOL, MOL NyRt., Budapest 1039, Szent István utca 14. \\ kercsmar.zsolt@mbfsz.gov.hu, budai.tamas@mbfsz.gov.hu,kaszuro@mol.hu, selmeczi.ildiko@mbfsz.gov.hu,musitz.balazs@mbfsz.gov.hu, \\ lantos.zoltan@mbfsz.gov.hu
}

\section{Cenozoic formations of the Strázsa Hill at Zsámbék and its surroundings}

\begin{abstract}
In the course of the geological mapping in the Zsámbék Basin, the Cenozoic succession — exposed in the quarry of the Strázsa Hill — was accurately documented. Moreover, analyses of palaeontological, stratigraphic and tectonic data were also conducted. The Middle Triassic dolomite is overlain by a relatively thin middle-upper Miocene succession of discontinuous appearance; its lower section is made up of fine-grained siliciclastic deposits (silt - medium grained sand) and carbonates of late Badenian (late Langhian - early Serravallian) age. The freshwater limestone, unconformably overlying the latter, is considered as the basal formation of the upper Miocene (Pannonian) succession of the Zsámbék Basin. The Pannonian succession characterised by considerable thickness and areal extent in the Zsámbék Basin is missing due to denudation, and the algae-bearing freshwater limestone is directly overlain by an alluvial-proluvial succession of Pleistocene age. Based on the analysis of sedimentological characteristics and the study of fossils the Neogene sedimentary environment shows particular features in many respects. At the beginning of the late Badenian sedimentation took place in a protected, coastal, lower salinity lagoon behind the palaeomorphologic ridge (island or peninsula) located along the Vértessomló-Nagykovácsi Zone. The lagoon received a large amount of sediment influx of fine-grained clastic deposits. Simultaneously, on the southern side of the island a rocky shore (characterised by abrasion) could be reconstructed. We detected freshwater influx during the late Badenian. In the Sarmatian it became restricted and at the beginning of the late Miocene a lacustrine environment came into being. During the Neogene-Quaternary structural evolution of the Vértessomló-Nagykovácsi Zone of W-E strike, several phases could have been identified. The earliest one among them is the small-scale thrusting of the Triassic dolomite over the middle Miocene succession, which can be coeval with the deposition of the late Badenian siliciclastic succession. The activity of the tectonic zone in the Sarmatian is indicated by the extremely thin occurrence and unconformable setting of the succession. The next structural phase is indicated by lateral striae observed on the Pannonian freshwater limestone; this phase corresponds to D11 transpressional deformation phase identified in the Gerecse. Uplift occurring in the course of the youngest deformation process of the tectonic zone resulted in the denudation of the Pannonian succession. This process may have been taken place during the Pliocene - early Pleistocene.
\end{abstract}

Keywords: Zsámbék Basin, Cenozoic, stratigraphy, basin and structural evolution, late Badenian palaeoenvironment

Összefoglalás

A Zsámbéki-medence földtani térképezése során részletesen felvettük a Strázsa-hegy kőfejtője által feltárt kainozoos rétegsort, valamint elvégeztük az őslénytani, rétegtani és tektonikai adatok elemzését. A középső-triász dolomitra viszonylag vékony és hézagos középsô-felső-miocén rétegsor települ, amelynek alsó szakaszát felső-badeni, középsố szakaszát szarmata finomszemcsés sziliciklasztitok (kőzetliszt - középszemcsés homok) és karbonátok alkotják. Az e fölött üledékhézaggal települő édesvízi mészkő a Zsámbéki-medence felső-miocén (pannóniai) rétegsorának bázisképződménye. A Zsámbéki-medencében általános elterjedésú pannóniai üledékek a Strázsa-hegyen lepusztultak, az algás édesvízi mészkőre közvetlenül pleisztocén alluviális-proluviális rétegsor települ. A szedimentológiai jellegek és az ősmaradványok elemzése alapján rekonstruált neogén üledékképződési környezet több vonatkozásban is egyéni jellegeket mutat. A késő-badeni során kezdetben csökkent sótartalmú, partmenti védett lagúnában zajlott az üledékképződés a Vértessomló-Nagykovácsi-zóna mentén kiemelkedő paleomorfológiai hát (sziget vagy félsziget) mögött, amelybe jelentôs mennyiségú finomszemcsés törmelék áramlott. Ezzel egy idôben a sziget déli oldalán sziklás abráziós part rekonstruálható. A lagúnába a késô-badeni során édesvízi hozzáfolyás zajlott, ami a szarmata során elzáródott, végül a késő-miocén elejére tavi környezet jött létre. A Strázsa-hegyen keresztülhaladó Ny-K-i csapású Vértessomló-Nagy- 
kovácsi-zóna neogén-kvarter szerkezetfejlődésén belül több szerkezeti fázist sikerült azonosítani. Ezek közül a legidősebb a triász dolomit kismértékú rátolódása a középső-miocén rétegsorra, amely a késő-badeni sziliciklasztos rétegsor leülepedésével egyidős lehet. A tektonikai zóna szarmata aktivitására utal a rétegsor szélsôségesen vékony kifejlődése és diszkordáns települése. A következő szerkezeti fázist a pannóniai édesvízi mészkövön észlelt oldalirányú vetôkarcok jelzik, ez a fázis megfeleltethető a Gerecse D11-es transzpressziós szerkezeti fázisának. A szerkezeti zóna legfiatalabb deformációja során zajlott kiemelkedés a pannóniai rétegsor lepusztulását eredményezte, amely a pliocénkora-pleisztocénre tehető.

Tárgyszavak: Zsámbéki-medence, kainozoikum, rétegtan, medencefejlődés, szerkezetalakulás, késô-badeni ôskörnyezet

\section{Bevezetés — kutatási elózmények}

A Gerecse földtani térképezésének lezárulását követően a Magyar Bányászati és Földtani Szolgálat 2018-ban indította el új térképezési programját, amelynek során felvételre kerül a Dorogi- és a Zsámbéki-medence, a Pilis, valamint a Budai-hegység É-i része. Az új felvételezés kezdeti szakaszában a terület jelentôsebb feltárásainak részletes vizsgálatát végezzük el a rétegtani felépítés és a fácieskapcsolatok főbb jellegeinek tisztázásához. Ennek során áttekintettük a területet érintő kutatásokat, és a kainozoos képződmények megismerése céljából részletes szelvényezést végeztünk a Zsámbék és Mány közötti Strázsa-hegy kőfejtôiben, ahol a bányászat eddig részletesen nem vizsgált neogén rétegsort tárt fel a triász képződmények fedőjében. A területen folyó térképezéssel együtt szerkezeti mérésekre és szerkezetelemzésre is sor került. Jelen értekezés erre a szúkebb területre (Strázsa-hegy és környéke) vonatkozó fontosabb megfigyeléseket és megállapításokat ismerteti. A terület képződményeinek megismerésének kezdetei a 19. század közepére nyúlnak vissza. A Buda és Tata közötti terület földtani képződményeivel foglalkozó leírásában már HANTKEN (1861) is számos „harmadkori képletet” különített el, amelyek közül Zsámbék térségében elsôsorban az „oligocen tengeri homokkô", illetve a „tengeri neogen képlet”-be sorolt „,cerithiummész” és „,congeriaagyag” jelentős.

LIFFA (1905) Tinnye és Perbál térségében folytatott agrogeológiai felvételezésében részletes leírást közölt a Zsámbék földtani felépítésében meghatározó szerepet játszó szarmata képződmények felszíni elterjedéséről, jellegéról és az akkori kőfejtókről (pl. Nyakas-hegy).

A dorogi szénterület felvételezéséhez kapcsolódóan FERENCZI (1923) végzett földtani térképezést a Zsámbékimedence É-i részén, Tinnye környékén. A terület kainozoos rétegsorában a következô rétegcsoportokat különítette el: „alsó oligocén hárshegyi homokkő csoport”, ,felsố oligocén rétegcsoport" (ez tartalmazza a cyrenás agyag és a pectunculusos homokkő kifejlődéseket), ,szarmata agyag, mészkő, kavics”, ,pontusi agyag, homok, kavics”, „levantei édesvízi mészkớ”, ,pleisztocén lösz, futóhomok” és ,ártéri, jelenkori üledékek". A herceghalmi artézi kút fúrása során ismertté vált „mediterrán” képződményeket (HALAVÁTs 1892) a térképezési területen FERENCZI nem tudta kimutatni a felszínen; hiányukat denudációval magyarázta.

Zsámbék környékének legutóbbi részletes földtani felvételezését a Magyar Állami Földtani Intézet Középhegységi
Osztálya hajtotta végre 1977 során, azonban az 1:20 000-es méretarányú földtani térkép és az észlelések leírását tartalmazó alapadatgyújtemény (BAKONY et al. 1977, PARTÉNYI \& RADICS szerk. 1979), valamint a terület földtani felépítésének összefoglalása (JÁMBOR 1980a) kéziratban maradt.

A Mányi- és a Zsámbéki-medence neogén képződményeivel kapcsolatban JÁMBOR (1967, 1969, 1975a, b, 1977) folytatott kutatásokat, amelynek eredményeképpen — igazodva a Magyar Rétegtani Bizottság Miocén Albizottsága által 1977 májusában elfogadott nevezéktanhoz — elvégezte a Zsámbék környéki neogén képződmények litosztratigráfiai besorolását is (JÁMBOR 1977). A területen a $300 \mathrm{~m}$ legnagyobb vastagságot is meghaladó neogén összletet kőzettani jellegek alapján hat jellemző kifejlődésú egységre osztotta; amelyek faunisztikai szempontból is jól elkülöníthetők egymástól (I. táblázat). Közülük az alsó kettőt

I. táblázat. A Zsámbéki-medence neogén összletének rétegtani tagolása JÁMBOR (1977) és a Magyar Rétegtani Bizottság (MRB) jelenleg érvényes felosztása szerint (Gyalog et al. 1996, Gyalog \& BuDAI szerk. 2004, Csillag \& SZTANó 2015)

Table I. Stratigraphic classification of the Neogene formations of the Zsámbék Basin by JAMBOR (1977) and by the Hungarian Commission on Stratigraphy (MRB, GyalOg et al. 1996, GYaLOG \& BUdAI eds. 2004, CSILLAG \& SZTANó 2015)

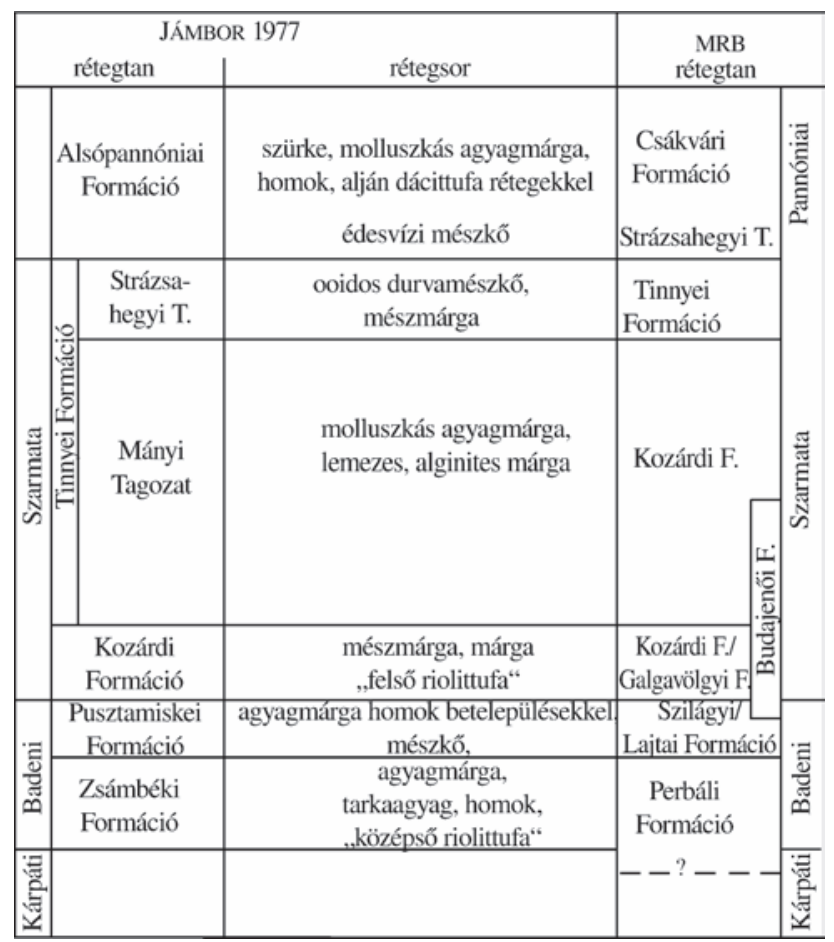


(„Zsámbéki Formáció” és „Pusztamiskei Formáció”) a badenibe, a középső hármat („Kozárdi Formáció”, „Tinnyei Formáció Mányi Tagozat” és „Tinnyei Formáció Strázsahegyi Tagozat”) a szarmatába, a felsôt pedig az „Alsópannóniai Formáció”-ba sorolta. A JÁMBOR (1977) által Zsámbéki Formációként elkülönített szárazföldi eredetû képződményeket jelenleg a Perbáli Formációba soroljuk. Figyelemre méltó, hogy kezdetben e képződményeket JÁMBOR még a badeni emelet idősebb részébe helyezte. A késôbbiekben e szárazföldi eredetû, mélyebb részén tufit-, tufitos agyagbetelepüléseket is tartalmazó összlet korát — a középső riolittufa kárpátiba sorolása miatt — a kárpáti-kora-badeniben rögzítették (JÁMBOR 1980a, 1996a). JÁMBOR (1980a) szerint e miocén szárazulati képződmények hiányoznak a Strázsa-hegy-Gutkő-hegy vonulatában. A „Zsámbéki Formáció”-ból (azaz a jelenlegi Perbáli Formációból) fokozatosan kifejlődő, középsô-késô-badeni korú Szilágyi Agyagmárga Formáció JÁMBOR (1977, 1980a) munkájában Pusztamiskei Formáció néven szerepel. A Bakony térségéből ismert, és a mai értelemben vett Pusztamiskei Formációba sorolt tengeri üledékek képződése azonban a kora-badeni során ment végbe, ezek a Zsámbéki-medencében nem mutathatók ki (SELMECZi 2004, 2015).

JÁMBOR (1977) a következő litosztratigráfiai egységeket különítette el a szarmatán belül (I. táblázat): (1) idősebb szarmata mészmárga-, márgarétegsor riolittufa-betelepüléssel (Kozárdi Formáció), (2) a szarmata emelet magasabb részében előforduló molluszkás agyagmárga, lemezes, alginites agyagmárga és cystoseirites márgakifejlődések (Tinnyei Formáció Mányi Tagozata), (3) ooidos durvamészkő, zátonymészkő és mészmárga kifejlődések, amelyek a szarmata emelet legfiatalabb részét képezik (Tinnyei Formáció Strázsahegyi Durvamészkő Tagozata). Az „oolitos-molluszkáscardiumos és pirenellás — továbbá spirorbisos-hydroideses mészkő" 10-80 cm-es rétegeinek váltakozásából álló összletben valódi zátonyképletek is felismerhetők. JÁMBOR szerint ez a kifejlődés fooként a korábban kiemelt triász-oligocén rögök felett települ. A Kozárdi Formáció fehér, vékony mészmárga, márga rétegsorában JÁMBOR három, több kilométeren át követhető vezérszintet említett, amelyek közül a legfigyelemreméltóbb a „,felsố riolittufá”-nak megfelelő, néhány dm vastag, vízbehullott biotitos dácittufa. A tufaszint mellett említésre érdemes a többnyire az alatt települő decapodás mészmárga, illetve a felette kifejlődött articulinás márgaréteg. JÁMBOR (1977) szerint a szarmata összlet fedőjében konkordánsan települ az „Alsópannóniai Formáció”-ba sorolt szürke, molluszkás agyagmárga és homok, alján dácittufa rétegekkel, legalsó szakaszán édesvízi mészkővel (JÁMBOR 1980a). Az 1990-es évektől Zsámbéki Formációként (JÁMBOR 1996b) elkülönített képződmény (és azon belül a Strázsahegyi Tagozat édesvízi mészköve) jelenleg a Csákvári Formációba tartozik (CSILLAG \& SzTANó 2015).

A terület badeni és szarmata képződményeinek lito- és biosztratigráfiai vizsgálatáról KóKAY (1989) adott összefoglalást mintegy 40 fúrás rétegsorának feldolgozása alapján. JÁMBOR $(1977,1980 c)$ megfigyeléseivel összhangban ő is megállapította, hogy a térségben a badeni képződmények megjelenését megelőzően hosszú szárazföldi időszak állt fenn, amelynek során a felső-oligocén rétegsor felső (20-30 m vastagságú) része szárazföldi mállást szenvedett. A lepusztulás mellett az oligocén összlet tektonikusan kibillent, és a kis távolságon belül is jelentős mértékben változó kifejlődésû miocén rétegek eltérô dőléssel települtek rá. Az oligocén rétegsor fedőjében miocén szárazföldi összlet települ, amelynek vastagsága D felé növekszik és gyakran szeszélyesen változik. A Perbál-6 fúrásban harántolt szárazföldi összlet (ma Perbáli Formáció) mélyebb részén észlelt andezittufa betelepülés KóKAY szerint a Börzsöny-Visegrádihegység fô kitörésével párhuzamosítható, amely a korabadeniben zajlott. Ez a formáció kora- és középső-badeni korát igazolja. KóKAY (1989) tanulmányában felhívta a figyelmet a Mány-21 (jelenleg Mány-15) fúrás 216,9-283,8 m között harántolt szárazulati miocén rétegsorában észlelt, lagunáris kapcsolatra utaló képződményekre: a 232,7237,7 m közötti szakaszon (felfelé haladva) ,diatomalemezes" mészkő, lemezes márga, autigén breccsás dolomit, illetve ,diatomalemezes” mészkő figyelhető meg barnakőszén réteggel és felül Hydrobiákkal. Ez a lagunáris betelepülés véleménye szerint a D-i irányból érkező középsőbadeni transzgresszióhoz köthető. Megfigyelései szerint a szarmata kőzetek túlterjednek a badeni üledékeken, valamint a fiatalabb szarmata is túlterjed az idősebb szarmata képződményeken. A kora- és késő-szarmata határon üledékhézag valószínúsíthető, erre utal a Perbál-6 fúrásban megfigyelhető vékony tarkaagyag réteg (KóKAY 1989).

A Zsámbéki-medence nyolc szelvényérôl CORNÉE et al. (2009) és TóTH et al. (2009) közölt részletes szedimentológiai-őslénytani adatokat, amelyek idốben a legkésőbbi badenitől a késő-szarmatáig lerakódott képződményeket tárták fel. Véleményük szerint a szarmata üledékképződési környezetre meleg vizú, erősen hullámmozgatott, ingadozó sótartalmú, mezo-eutrofikus sekélytenger volt jellemző, amely túltelített lehetett a karbonátokra nézve. Az üledékképződés a kora-szarmatában alacsony hajlásszögú karbonátrámpán zajlott, amelynek belsô részén lagúnák alakultak ki. A szarmata végén ooidos üledékek progradációja volt jellemző, amelyek változó sótartalmú lagúnákban, szél és hullámzás által meghatározott körülmények között rakódtak le sekély vízmélységben.

A Budapest környékén, így a Zsámbéki-medence K-i peremén is a felszínen tanulmányozható szarmata karbonátok (Tinnyei Mészkő Formáció) leülepedési környezetének vizsgálatával PALOTÁs (2014) foglalkozott, aki a képződmények üledékföldtani, geometriai és kőzetszöveti jellegeit tanulmányozta. Eredményei szerint a szarmata karbonátos rétegek max. 20-25 m vízmélységú, részben karbonáthomok dombokkal szegélyezett karbonátrámpán, részben karbonátplatformon keletkeztek. Az üledékek és a partvonal jellegét erősen meghatározták a cunami jelenségek. Ciklussztratigráfiai értelemben a szarmata rétegsor alapvetően regressziós jellegú, amely felfelé sekélyesedő két alciklusból áll.

A legújabb kutatások (MBFSZ alapkutatási projektek) alapján az elmúlt években, kiegészítendô a korábbi eredmé- 
nyeket, a Zsámbék-Tök, illetve Páty területén elhelyezkedő feltárások, egykori kőfejtők vizsgálatára is sor került. A faunaegyüttes és a kőzetszöveti elemzések alapján az itt vizsgált kőzetek képződése a késő-szarmata idején,erősen mozgatott, időnként hiperszalinná váló, sekély lagúna környezetben történt (SELMECZI et al. 2018, PALOTÁs et al. 2019).

\section{Célkitúzés, módszerek}

A tanulmány célja, hogy bemutassa azokat az elsố szedimentológiai, őslénytani, rétegtani és szerkezetföldtani eredményeket, amelyek a zsámbéki Strázsa-hegy eddig még nem vizsgált kainozoos rétegsorával kapcsolatban megismerhetők voltak.

A zsámbéki Strázsa-hegy kainozoos rétegsorának megismerése céljából részletesen felvettük a bánya által feltárt legvastagabb hozzáférhető szelvényt, amelyet a terepi megfigyelések és a fényképek elemzése alapján korreláltunk az elérhetetlen falszakaszok rétegsorával. A begyújtött minták egy részét vékonycsiszolatban, más részét vizes és ecetsavas oldási feltárással iszapolási maradékként vizsgáltuk. Az őslénytani preparátumok részben az MBFSZ laboratóriumában, részben SzUROMINÉ KoRECZ Andrea (Mol Laboratóriumok) által készültek, aki egyben az őslénytani vizsgálatokat is végezte. A vékonycsiszolatokból az ôslénytani vizsgálatok mellett mikrofácies-elemzés is készült. A bányászat által feltárt kainozoos rétegsor azonosítása céljából feldolgoztuk a környékrôl rendelkezésre álló földtani irodalmi adatokat is.

A szerkezetalakulási fázisok meghatározásánál nem vettük figyelembe a paleomágneses mérésekról, a szeizmikus szelvények értelmezésérôl született irodalmi adatokat, ezekre a későbbiekben kerítünk sort. A szerkezeti adatfeldolgozási szoftverek közül a SASVÁRI \& BAHAREV (2014) által kifejlesztett SG2PS (structural geology to post script converter) programot használtuk. Ennek segítségével ábrázoltuk a vetôkarcokból számított feszültségirányokat, a litoklázisok, vetôkarcok sztereografikus projekcióit.

\section{Földtani felépítés}

\section{Mezozoos képzódmények és szerkezetföldtani jellemzók}

A Strázsa-hegy tágabb környezetét, a Zsámbéki-medencét Ny-on a Vértes és a Gerecse, míg K-en a Budaihegység mezozoos képződményekből álló vonulata határolja (1. ábra).

A medence aljzatát triász képződmények alkotják, amelyek csak szerkezeti elemekkel határolt zónák mentén bukkannak ki a medencét kitöltő kainozoos képződmények alól ( 1 . ábra). Ilyen zónába tartozik a Zsámbék és Mány közötti Strázsa-hegy is, ahol a Dunántúli-középhegység ÉK-i részének egyik meghatározó szerkezete, a Vértessomló-Nagykovácsi-vonal (1. még Környe-Zsámbék-vonal, FODOR 2008) mentén érintkezik a déli egységet alkotó Fődolomit az É-ról rátolódott karni vulkanittal és a középső-triász Budaörsi Dolomittal (BudAi et al. 2015, FARICs 2018, DunKL et al. 2019).

A Zsámbéki-medence területén felszínre bukkanó triász dolomit dőlése többnyire ÉÉNy-i irányú és meredek, a Gyermely és Szomor környéki kibúvásokban meghaladja a 40-50-ot (BUDAI et al. 2015). A zsámbéki Strázsa-hegyen a

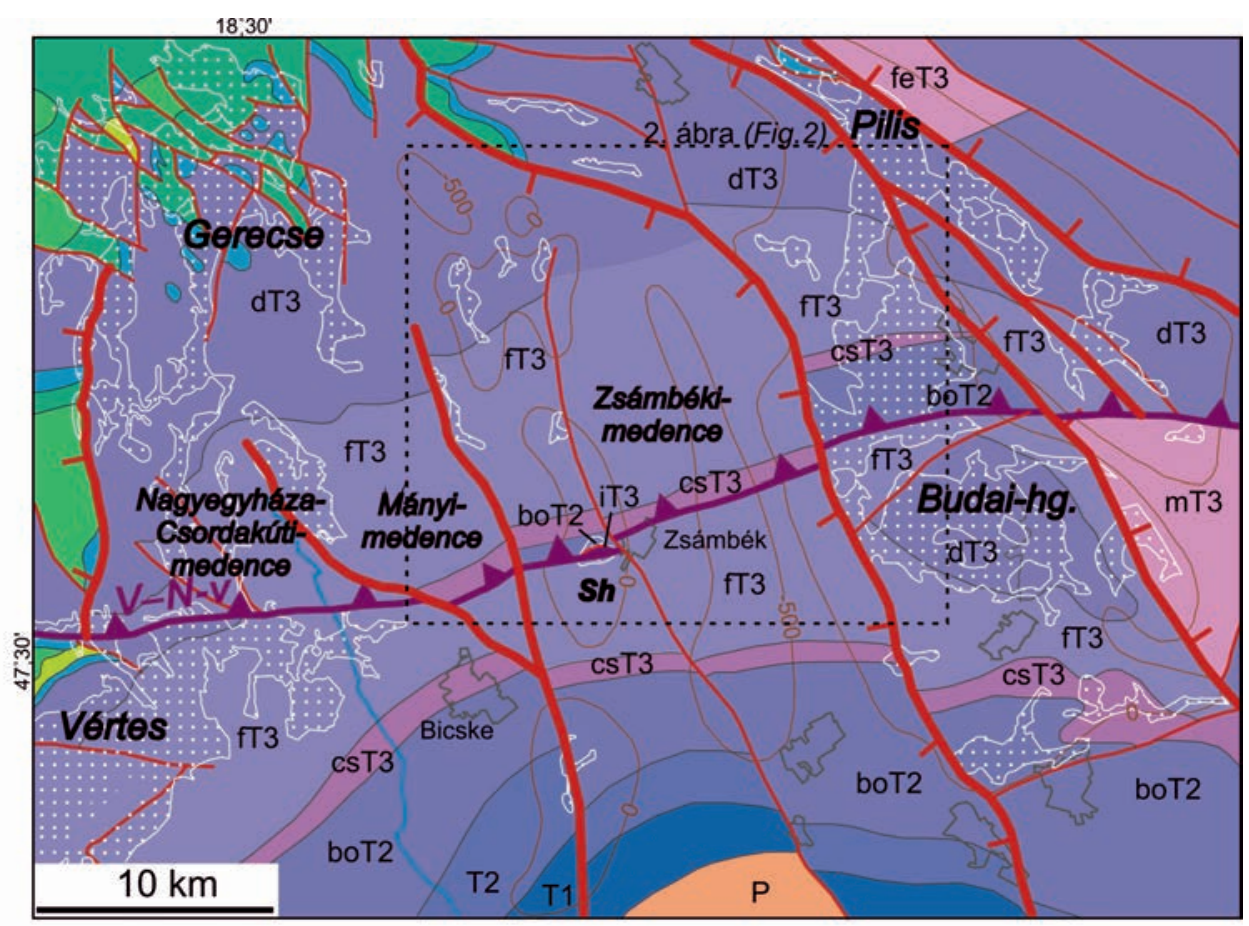

1. ábra A Zsámbéki-medence és környezetének pre-kainozoos aljzattérképe (HAAS et al. 2010 nyomán). Kékkel a jura, zölddel a kréta képződmények, a fehér pontozott mintázattal a pre-kainozoos képződmények felszíni elterjedési területe ábrázolt. A szintvonalak a medencealjzat domborzatát ábrázolják a tengerszint felett

Röviditések: P - felső-perm képződmények; T1 - alsó-triász képződmények; T2 - középső-triász képződmények; boT2 - Budaörsi Dolomit (felsö-anisusi-alsó-karni platform fácies); iT2 - Inotai Formáció (karni vulkanit); csT3 - Csákberényi F. (karni medence fácies); fT3 - Födolomit (karni-alsó-nori platform fácies); dT3 - Dachsteini Mészkỏ (nori-rhaeti platform fácies); feT3 - Feketehegyi Mészkő (nori medence fácies); mT3 - Mátyáshegyi F. (karni-nori medence fácies); V-N-v - Vértessomló-Nagykovácsi-vonal

Figure 1. Pre-Cenozoic basement-map of the Zsámbék Basin and surrounding areas (after HAAS et al. 2010). Blue: Jurassic formations, green: Cretaceous formations, white dotted areas: Pre-Cenozoic formation on the surface. Contour lines show the surface of the basement above sea-level

Abbreviations: P - Upper Permian formations; T1 - Lower Triassic formations; T2 - Middle Triassic formations; boT2 - Budaörs Dolomite (Upper Anisian - Lower Carnian platform facies); iT2 - Inota Fm (Carnian vulcanite) csT3 - Csákberény Fm (Carnian basin facies); fT3 - Hauptdolomit (Carnian - Lower Norian platform facies); dT3 - Dachstein Limestone (Norian-Rhaetian platform facies); feT3 Feketehegy Limestone (Norian basin facies); $m T 3$-Mátyáshegy F. (Carnian-Norian basin facies); $V$-N-v -Vértessomló-Nagykovácsi line 
Budaörsi Dolomit dólése ugyancsak $60^{\circ}$ a VértessomlóNagykovácsi-vonaltól északra lévő pikkelyben. BUDAI et al. (2015) rámutatott, hogy monoklinális dólést feltételezve ilyen dólésértékek mellett a felső-triász dolomittest vastagsága meghaladná az $5 \mathrm{~km}-\mathrm{t}$ az elterjedésük térképi szélessége alapján, ez azonban a legnagyobb ismert vastagságértékekkel számolva is képtelenség. A Zsámbéki-medence és a Ny-ra szomszédos Mányi- és Nagyegyházi-medence aljzatát ért több száz fúrás alapján több korábbi szerző is feltételezett rétegismétlődéseket (VÉGHNÉ et al. 1988), illetve azok kiváltó okaként DK-i vergenciájú feltolódásokat a triász képződmények ÉK-DNy-i csapású, pásztás elrendezôdésében (ORAVECZ \& HAAS 1980; KERCSMÁr 2004), amelyek a Budaörsi Dolomittól a Fődolomitig terjedô rétegsor többszöri ismétlődését eredményezhették. Ilyen szerkezethez kapcsolódik az igen meredek $\left(40-70^{\circ}\right)$ dőlésú anisusiladin medencefáciesú rétegsor megjelenése is a Zsámbék és Mány közötti fúrásokban (BUDAI 2004). BUdAI et al. (2015) feltételezte, hogy a felsô-triász dolomit pásztájának jelentôsen megnövekedett szélessége tektonikai okokra vezethetô vissza a Vértes-Gerecse vonulata és a Budai-hegység között, ahogy ezt korábban ORAVECZ \& HAAS (1980), valamint BALLA \& DUDKO (1989) is felvetette.

A Vértessomló-Nagykovácsi-zóna múködési idejével és jellegével kapcsolatosan többféle értelmezés is született. CsÁsZÁr et al. (1978) térképén kréta korú rátolódásként (a jelenleg igazolt helyétól délebbre) van feltüntetve, míg MAROS (1988) — ettôl némi eltéréssel - főként fiatal balos eltolódásként értelmezte a Vértes É-i peremén. BALLA \& DuDKO (1989) a vonal Vértest metszố szakaszán a balos, míg a Zsámbéki-medencét átszeló középső és a budai-hegységi keleti szakaszán a jobbos miocén oldalelmozdulást tartotta a legvalószínúbbnek. FoDOR et al. (1994) budai-hegységi adatok alapján a szerkezetet eocén jobbos eltolódásnak tekintette, viszont annak vértesi szakaszát - BALLA \& DUDKO (1989) korábbi munkájától eltérô térképi rajzolattal — a mezozoos kibukkanásoktól északra húzta meg. Késóbb a Vértes földtani térképezésének eredményei alapján a szerkezet Környe és Zsámbék közötti szakaszát középső-albai, esetleg késő-kréta rátolódásként értelmezték (FoDOR \& Bíró 2004, Fodor et al. 2005, FodOr 2008). KerCSMÁr (2005) a Tatabányai-medencében a szerkezeti zóna jobbos eltolódásos felújulását igazolta az eocén során

A Strázsa-hegy triász dolomitból álló blokkja a Zsámbéki-medence É-i részmedencéjének középsô részén található (1. ábra). A geofizikai mérések és fúrásadatok alapján szerkesztett aljzattérképek (GIDAI 1979, HAAs et al. 2010) szerint az É-i medencerészt egy olyan normálvető osztja ketté, amely a Mányi-medence K-i peremvetőjétől 2-2,5 km-re K-re, nagyjából a zsámbék-szomori út vonalában húzódik. Párhuzamosan fut a fó peremvetôkkel (FoDOR et al. 2000) és belefut a Vértessomló-Nagykovácsi-zónába.

A kainozoos szerkezetalakulásokhoz kapcsolódó tektonikai és üledékföldtani kutatások szerint (FODOR et al. 2000, PALOTÁs 2014) a Zsámbéki-medence É-D-i tengelyú süllyedéke, egymással szemben dőlő aszimmetrikus félárokrendszert alkot, amelyet az ún. „Etyeki-hát” mint transzferzóna választ el egymástól. Az É-i medencerész Ny-i határát a Mányi-medence Ny-ra dőlő K-i fővetője, K-i határát pedig a Budai-hegység szintén Ny-ra dőlő Ny-i peremtörése képezi. A D-i medencerész Ny-i peremvetôje ezekkel ellentétesen Kfelé dől. Szerkezetelemzésük alapján a normálvetốk múködése és az ehhez kötődô transzferzóna létrejötte már a szarmatában megkezdődött, és aktív volt a szarmata üledékképződés alatt (szinszediment félárokszerkezetek) és azt követően is, a kora-pannóniai vagy akár a pliocén során is. Ezek alapján a medence fó geometriáját kialakító szin- és posztszediment törések azonos feszültségtérben keletkeztek.

\section{Kainozoikum}

A Zsámbék környezetében mélyített fúrások alapján a térség földtani felépítésében jellemzően néhány száz m, de helyenként akár a $700 \mathrm{~m}$-t is megközelítő vastagságú (Zsámbék Zs-14 fúrás: $684 \mathrm{~m}$ ) kainozoos képződményegyüttes vesz részt.

\section{Eocén képzôdmények}

GIDAI (1979) szerint a Zsámbéki-medencében eocén képződmények egyedül a Zsámbék Zs-1 jelú fúrás rétegsorából mutathatók ki. A Strázsa-hegytől ÉK-re 2 km távolságra esô fúrás a Dorogi Formáció Annavölgyi Tagozatának megfelelő széntelepes összletet (szén, agyagos szén, szenes agyag), és a rátelepülő miliolinás-alveolinás karbonátos rétegsort (Szőci Mészkő Formáció, Kincsesi Tagozat) fúrta meg $\mathrm{kb} .30 \mathrm{~m}$ vastagságban.

\section{Oligocén képzôdmények}

Zsámbék környezetében a Csatkai és a Törökbálinti Formáció, illetve ezek tagozatai mutathatók ki. A térségben az alluviális, ártéri környezetben keletkezett Csatkai Formáció jelenléte alárendelt, és az ehhez sorolt Sárisápi Tagozat kaolinos homokköve is csak néhány fúrásban nyomozható, vastagsága maximálisan $20 \mathrm{~m}$ körüli. Zsámbék környékén a legelterjedtebb oligocén képződmény a Törökbálinti Formáció Mányi Tagozata, amelyet csökkent sós vízi, sekélylagunáris kifejlődésú, uralkodóan finomszemú törmelékes üledékes kőzetek építenek fel. Kisebb kibukkanásai Zsámbéktól Ny-ra, ÉNy-ra nyomozhatók. Képződményei Ny felé, a Gerecse irányába összefogazódnak a szárazföldi Csatkai Formáció rétegeivel (BERNHARDT \& INCZE 1998). A Mányi Tagozat maximális vastagsága a területen meghaladja a 300 m-t, jellemzően 150-250 m között változik. A tagozat bázisán, vagy a képződményei közé települve kis vastagságban helyenként szenes rétegek is megfigyelhetốk (Törökbálinti Formáció Mogyorósi Tagozat, Zsámbék Zs-4, -14 jelú fúrások).

\section{Miocén képződmények}

A Perbáli Formációt cikluskezdô tarkaagyag, mészkonkréciós agyag, agyagmárga, homok, homokkő, kavicsos homok rétegei építik fel. A rétegsor alsó részében tufa-, tufit-, illetve bentonit-, bentonitosagyag-betelepülések jelenhetnek meg. A vulkáni eredetú közbetelepülések a 
„középső riolittufa” szórással (Tari Dácittufa Formáció) hozhatók kapcsolatba. A formáció eróziós és szögdiszkordanciával települ az oligocén képződményekre (KóKAY 1989, JÁMBOR 1977). A Mányi-medencében a Perbáli Formációra üledékfolytonosan a Szilágyi Agyagmárga, diszkordánsan pedig szarmata képződmények települnek.

A területet a badeni korszakban elérô transzgresszió a Szilágyi Agyagmárga Formáció normál sótartalmú sekélytengeri, nyíltvízi képződményeinek lerakódását eredményezte. A Mányi- és a Zsámbéki-medencében a formációt szürke, zöldesszürke agyagmárga, aleuritos agyagmárga, finomhomokos aleurit, márga, illetve homok, homokkő alkotja (JÁMBOR 1980a). Uralkodó kőzettípus a lemezeskagylós elválású, szürkészöld agyagmárga, amely gazdag molluszkafaunát tartalmaz. Gyakoriak a Cardium, Corbula és Pirenella fajok. Az agyagmárga rétegeivel váltakozva, vagy fóként azok alatt — Pecten, Spondylus és Ostrea fajok dominanciájával jellemzett —, szürkészöld homok, illetve laza, meszes kötőanyagú, középszemú homokkő, vagy apró kvarckavicsos homokkő rétegek figyelhetôk meg. Vastagsága JÁMBOR (1980a) szerint 3-22 m között változik, átlagos vastagsága $15 \mathrm{~m}$, és csak fúrásokból ismert. A Szilágyi Agyagmárga vagy a Perbáli Formációra vagy idősebb képződményekre települ. A Szilágyi Agyagmárga Formáció képződményei Zsámbéktól Ny-ra és Mány környezetében számos fúrásból ismertek. A Mányi-medence e formációba sorolható képződményei a puhatestü- és foraminiferafauna alapján a késő-badeni során képződtek (JÁMBOR 1977).

A Lajtai Mészkő Formáció Rákosi Mészkő Tagozata a térség rétegsorában alárendelt szerepet játszik, és csak fúrásokból ismert. A badeni összlet felső harmadában, a Szilágyi Agyagmárgából kifejlődve, illetve azzal laterálisan összefogazódva jelenik meg. A formációt homokos mészkő, mészhomokkő, likacsos molluszkás mészkő képviseli, amelyben a jellemző alakok a Pectenek és az Ostreák. A molluszkák mellett gyakoriak a Borelis genusba tartozó foraminiferák. Puhatestú- és foraminiferafaunája alapján a kôzet a későbadeni során képződött (MüLLER in GyAlOG, BUDAI szerk. 2004).

A Zsámbéki-medence hiperszalin üledékei már több évtizede ismertek (JÁMBOR 1976, 1978). A badeni és szarmata gipsz, anhidrit, terméskén (terméskénné alakult gipsz) és alga eredetú szerves anyagban dús pelites kőzetek, továbbá mészkő- és dolomitrétegek váltakozásaiból álló képződményeket a Budajenői Formációba soroljuk (JÁMBOR 1975, RAVASZ 1978, RAVASZ \& Solti 1980, SzUROMIKORECZ \& SELMECZI 2015). A formáció elterjedése a Zsámbéki-medence K-i részére jellemző; legnagyobb vastagsága 60 m körül van (Budajenő Bő-2 és -6 jelú fúrások).

A Mányi- és a Zsámbéki-medence nyílt tengeri szarmata kifejlődése a Kozárdi Formáció, amelyet zömmel a zöldesszürke, zöld, lemezes, olykor leveles kifejlődésú agyagmárga, aleuritos agyagmárga alkot, helyenként nagy mennyiségú molluszkával (Cardium félék, Musculus sarmaticus). A Kozárdi Formáció jellemző vastagsága Zsámbék térségében néhány m-tôl 135 m-ig változik. Képződése az egész szarmata korszak során folyhatott. Üledékei fél sós vízi - tengeri üledékgyưjtő nyíltabb területén képződtek (SELMECZi 2008).

Zsámbék környékén jelentős felszíni elterjedésben tanulmányozhatók a szarmata Tinnyei Mészkő Formáció képződményei (2. ábra, A). A formáció fő tömegét szürkésfehér, sárgásfehér, illetve szürke biogén mészkő (molluszkás durvamészkő, cerithiumos mészkő, ooidos mészkő) és

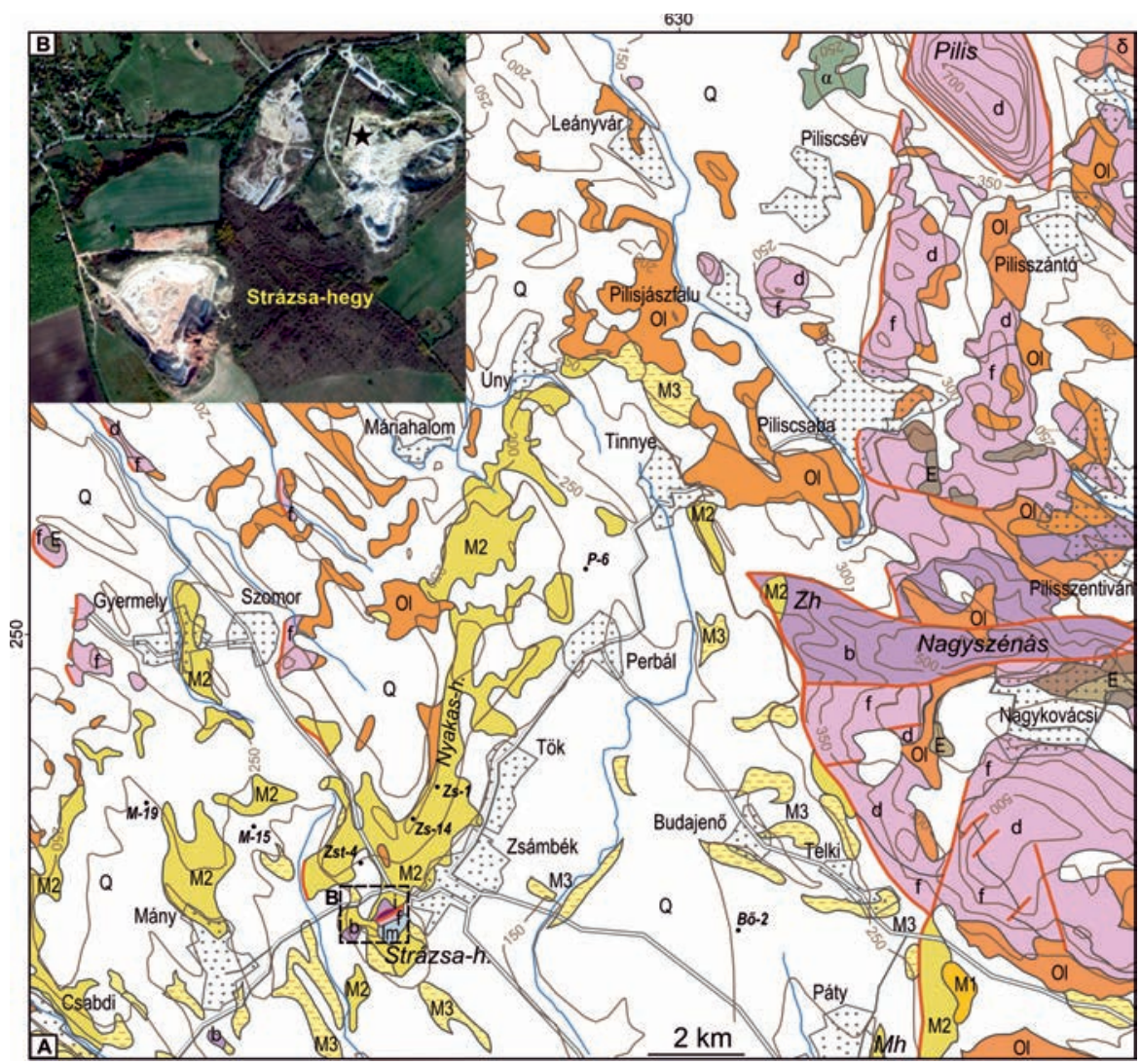

2. ábra. A Zsámbéki-medence földtani térképe (BUDAI, GYALOG szerk. 2009 nyomán), a szövegben szereplő fontosabb fúrások feltüntetésével. A Strázsa-hegy légifotójának (B) helyét a térképen szaggatott körvonal, a részletesen feldolgozott szelvény (3. és 4. ábra) helyét pedig a fényképen csillag jelzi

Röviditések: Mh - Mézes-hegy (Páty); Zh - Zajnát-hegy (Perbál). Triász: b - Budaörsi Dolomit; i - Inotai Formáció (karni vulkanit); f - Fődolomit; d - Dachsteini Mészkő; kainozoikum: E - eocén képződmények tagolás nélkül; Ol - oligocén képződmények tagolás nélkül; M1 - alsó-miocén képződmények tagolás nélkül; M2 - szarmata mészkő (Tinnyei F.); M3 -felsőmiocén (pannóniai) képződmények; Q - kvarter képződmények tagolás nélkül; lm - édesvízi mészkő; - andezit, - dácittufa

Figure 2. Geological map of the Zsámbék Basin (after BUDAI, GYALOG eds. 2009) showing the most important drilled cores mentioned in the text. Contour of aerial photo of Strázsa Hill $(B)$ is shown on the geological map by dashed rectangle. Place of the geological profile studied in details (Figs. 3 and 4.) is pointed by asterisk in the photo Abbreviations: Mh-Mézes Hill (Páty); Zh-Zajnát Hill (Perbál). Triassic: b- Budaörs Dolomite; $i$-Inota Fm (Carnian vulcanite); $f$ - Hauptdolomit; $d$-Dachstein Limestone; Cenozoic: E - Eocene formations; Ol - Oligocene formations; M1 - lower Miocene formations; M2 - Sarmatian limestone (Tinnye Fm); M3 - upper Miocene (Pannonian) formations; Q - Quaternary formations; lm-freshwater limestone; - andesite; -dacite tuff 
molluszkás mészhomok, mészhomokkő képezi. Ide soroljuk a mésziszap kifejlődéseket is. Mánytól É-ra a szarmata ooidos mészkőben fosszilis talajbetelepülések és szárazföldi csigakövületek (Helix) figyelhetôk meg (JÁMBOR et al. 2003). A formáció Zsámbék környékén többnyire a Kozárdi Formációra települ; abból üledékfolytonosan fejlődik ki, illetve laterálisan össze is fogazódhat vele. A szarmata üledékgyúijtó Ny-i peremén (pl. Vasztélypuszta térségében) túlterjedő módon a Mányi Formációra települ üledékhézaggal (Mány M-112, Csabdi Cso-105, -126 jelú fúrások). A szarmata üledékgyújtő K-i peremén, a Budai-hegység ÉNy-i részén (pl. a Nagyszénás vonulatához tartozó perbáli Zajnát-hegyen) a Tinnyei Mészkő abráziós konglomerátummal települ a triász alaphegységre (SEMPTEY 1943). Fedôjében üledékhézaggal a Csákvári Formáció, vagy kvarter üledékek (lösz, deluviális lerakódások stb.) következhetnek. A Tinnyei Formáció ôsmaradványokban többnyire gazdag, legjellemzóbb fosszíliák a molluszkák és a foraminiferák. A pátyi Mézes-hegyen gyakoriak a ránövő foraminiferák, a nubeculariák (Sinzowella novorossica novorossica). $\mathrm{Az}$ ősmaradványanyagban vörösalgák (Hydrolithon sp.), bryozoák, illetve ostracodák is megfigyelhetók. A Mézeshegyen különösen sok a biogén komponens; a ránövôbekérgező szervezetek tömeges jelenléte miatt a kőzet igen kemény és kompakt megjelenésú (PALOTÁs et al. 2019).

A szarmata összletbe települő, korábban felső-riolittufa néven leírt képződmények a Galgavölgyi Riolittufa Formációba tartoznak. A formációt a vizsgált területen a hullott tufaanyag jellemzi, amely fôként a Kozárdi Formációban figyelhetô meg közbetelepülésként. Vastagsága többnyire néhányszor $10 \mathrm{~cm}$, maximálisan 1-2 m-re tehető. A finomszemú tufa légi szállítás útján került az üledékgyújtókbe (SelmeCZI 2008).
A középső-miocén rétegsorra a pannóniai Csákvári Formáció üledékei települnek. Ez az összlet a Pannon-medence szigeteinek a nyílt víztôl különböző mértékben elzárt, főként sekély vízi környezetében rakódott le 11,6-10,6 millió évvel ezelőtt (Csillag, Sztanó 2015, Magyar 2010).

A miocén rétegsorra települő kvarter képződmények közül jelentôs területeket borít a késô-pleisztocén lösz és a különböző deluviális üledékek.

\section{A Strázsa-hegy kainozoos rétegsorának jellemzése}

A Strázsa-hegy legteljesebb kainozoos rétegsorát a kôfejtô Ny-i fala tárja fel (3. ábra, helyszínét a 2. ábra B légifotó mutatja). A közel É-D-i csapású szelvényben az erősen összetört Budaörsi Dolomit erodált felszínére települő rétegsor három részre bontható a kőzettani összetétel és a települési jellemzők alapján. A legidősebb, kb. 14 m vastag alsó szakasz túlnyomó részben közép- és finomszemcsés sziliciklasztos képződményekből áll (1-15. réteg), amelyet felfelé vékonyabb-vastagabb karbonátos rétegek közbetelepülése tarkít (3. ábra) (,A” rétegösszlet). E fölött diszkordanciafelületekkel határolt, 0,8-1,0 m vastag, kemény, algasávos, onkoidos mészkő települ (B rétegösszlet, 16. rétegcsoport). A felső, 3-4 m vastag legfiatalabb szakasz (C rétegösszlet, 17. rétegcsoport) túlnyomó részben meszes aleuritos (löszös) homokból, homokos meszes aleuritból áll, amely áthalmozott dolomittörmeléket és homokot tartalmaz. A szelvénytôl K-re esố területen ezt a képződményt barna paleotalajos löszsorozat fedi, amely a felvett szelvényszakaszon, feltehetôen bányászati tevékenység miatt hiányzik.

A szelvény D-i részén, közvetlenül a triász képződmé-

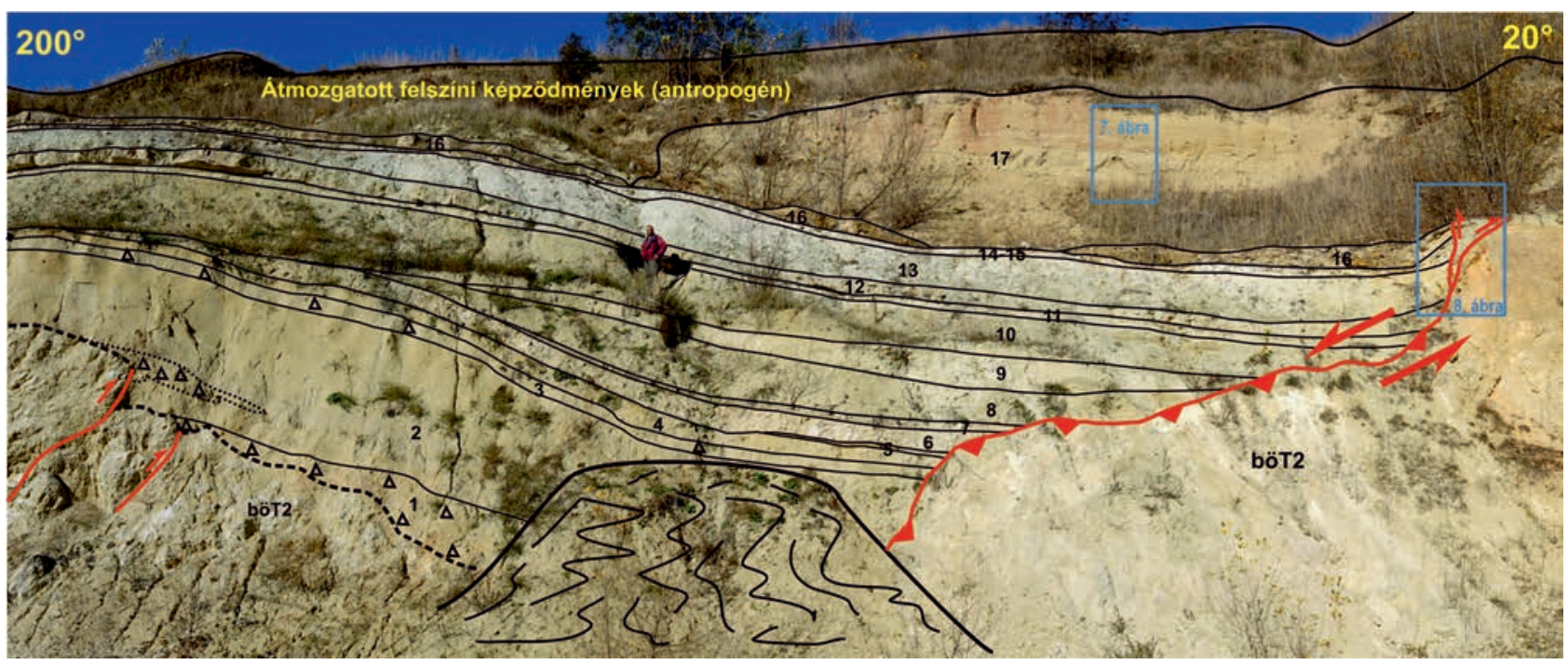

3. ábra. A zsámbéki Strázsa-hegy kőfejtőjének Ny-i falán feltárt szelvény rétegsora (nyomvonala a 2. ábra B részén látható). A szaggatott fekete vonal a Budaörsi Dolomit felszínét és a miocén képződmények települt határát, a piros vonal a triász és miocén képződmények tektonikus határát jelöli a deformáció jellegének megadásával (piros nyilak és háromszögek). A D-i oldal szinszediment deformációjához kapcsolódó breccsarétegeket fekete háromszögek mutatják. böT2 - Budaörsi Dolomit

Figure 3. Geological profile exposed on the western wall of the Strázsa Hill quarry near Zsámbék (track of the profile is shown in Figure 2, B). Black, dashed line indicates the surface of the Budaörs Dolomite and the stratigraphic boundary of the Miocene succession; red line indicates the tectonic contact between the Triassic and Miocene formations showing the type of deformation (red arrows and triangles). Breccia beds in connection with the synsedimentary deformation of the southern side are shown by black triangles. böT2 - Budaörs Dolomite 
nyekre települő „A” rétegösszlet alsó része D-rôl É felé vastagodó, D-i irányban kiékelődő rétegekből áll (3. ábra). A kiékelődő rétegeket a rétegcsoport felső szakasza fedi le a rétegvastagság minimális laterális változásával. Az efölött települő „B rétegösszlet” onkoidos, algás mészkő (16. réteg) rétegeinek alsó és felsô réteghatárán eróziós diszkordancia figyelhető meg.

A szelvény É-i részén a triász és a neogén képződmények tektonikusan érintkeznek. A szerkezeti zónába olyan törmelékes üledékek csípődtek, amelyek a szelvényben nem találhatók meg (1. „,szerkezeti zóna képződményei”).

$\mathrm{A}$, „C" rétegösszlet az „A és B” rétegösszlet, valamint kérdésesen a vetőbe csípett képződmények erodált felszínére települ.

$\mathrm{Az}$ „A rétegösszlet” további három részre osztható (4. ábra).

Alsó részén (1-5. rétegek) változó mértékben agyagos, aleuritos finom-, és közepes szemcseméretú kvarchomokból álló sziliciklasztos rétegek találhatók. A rétegsor bázisán lévő homokréteg 1-5 cm nagyságú, változó mértékben koptatott, gyengén kerekített vagy sarkos triász dolomitklasztokat tartalmaz, amelyek különböző mértékú, de nem nagy távolságú szállítást szenvedtek (1. réteg). A klasztok a kainozoos rétegsor fekvőjét képező triász képződményekkel azonos anyagúak. A homokszemcsék mérete a rétegen belül felfelé csökken. A bázistörmeléket tartalmazó rétegre 2 m vastag, ősmaradványmentes aleuritos finomhomok réteg következik (2. réteg), amelynek felsô részén ismét triász dolomitklasztok jelennek meg (3. réteg). A klasztok jól vagy gyengén koptatottak, kiválóan vagy közepesen kerekítettek. A bázistörmelékhez képest a dolomit anyagú törmelék mellett kvarckavicsok is megjelennek. A réteg felsô részén 4-10 cm átmérőjű, minden oldalukon 0,5-1 cm átmérôjú lukakkal sûrún bioperforált, triász dolomit anyagú abráziós parti kavicsok találhatók. A rétegsor ezen része egyre finomabb szemcsés homok, aleurit, majd agyagos rétegekkel zárul (4-5. réteg). A szerves anyag feldúsulását az agyag barna színe jelzi. Az agyagos rétegek felsô része vékonylemezesen, a mésztartalom növekedésével, mészgumók megjelenésével folyamatosan megy át a rétegcsoport felső szakaszára jellemző, egyre karbonátosabb rétegsorba.

A rétegcsoport középső szakasza 0,5 m vastag, tiszta „,chalk-jellegư” karbonátos réteggel kezdődik (6. réteg). A mikrites mészkő csupán néhány apró termetû, vékony falú foraminiferát tartalmaz. Fölötte — a fekvőjéhez hasonlóan szerves anyagban dús — rozsdabarna, világos drapp, majd szürkészöld agyagréteg található (7. réteg), amelyben feltûnően sok édesvízi ostracoda jelenik meg a csökkent sós vizet is elviselő foraminiferák mellett (l. következő fejezet, II. táblázat). Az agyagos rétegre folyamatosan 1,5-2,0 m vastag meszes homok, homokkő következik (8-9. réteg). A mésztartalom felfelé fokozatosan nó, és különösen a 9. rétegből diverz és jó megtartású fauna került elő amely normálsós, vagy ahhoz nagyon közeli sótartalmú, sekélytengeri lagúnakörnyezetet igazolt (1. következő fejezet, II. táblázat) Ezek a rétegek É felé vastagodnak, és D felé, a 6. réteg tetejére lapolódva kiékelődnek, aminek következtében az őket fedő képződmények (10-12. réteg) a szelvény $\mathrm{D}$-i felében a tiszta karbonátos rétegre (6. réteg) települnek. A rétegcsoport felsố szakaszán a rétegek anyaga felfelé finomodó törmelékszemcsékből álló, közép-, és durvaszemcséjű, meszes kvarchomoktól a laminált aleuritos agyagig változik (10-11. réteg). A rétegek legfelsô része mészgumóssá válik, hasonlóan a 4-5. réteghez. A laminált, mészgumós agyagrétegekre kemény mészkő pad (12. réteg) következik. Ezeket a rétegeket nagyon kevés, változó sótartalmat jelző foraminiferák (Miliolina-félék), és a normálnál jóval kisebb sótartalmat jelző ostracodák megjelenése jellemzi.

A rétegcsoport felső részén $2 \mathrm{~m}$ vastag szürke, aleuritos, finomhomokos, vékonyan rétegzett márga, meszes, agyagos homokkő (13. réteg) következik éles váltással és bizonytalan diszkordanciával az alatta fekvő mészkő rétegre (3. ábra, fénykép), amely D-i irányban túlterjed az alatta fekvő rétegsoron. Az innen előkerült néhány Globigerina sp. nyílt vízi, tengeri kapcsolat lehetőségére is utalhat. Tetejére $0,1 \mathrm{~m}$ vastag agyagos aleurit települ (14. réteg).

Erre 0,7 m vastag hófehér, apró lukakkal tarkított (kipergett vagy kimállott miliolidae- és ostracoda-vázak, (1. következő fejezet), finomhomokos, mikrites mészkő következik (15. réteg). A szegényes és rossz megtartású ôsmaradvány tartalma - egyedszámban és diverzitásban is — jelentősen elmarad a fekvő rétegsoréhoz képest (1. következő fejezet, II-III. táblázat), ami jelentős változásra utal.

$\mathrm{Az}$ „A” rétegcsoportra rendkívül kemény, átkristályosodott algaszônyegből, felszakított algaszőnyeg darabokból, onkoid szemcsékből álló (5. ábra), lukacsos, ősmaradványmentes, vékonyan rétegzett édesvízi mészkő (16. réteg) települ diszkordánsan (4. ábra) („B” réteg). A kemény mészkô rétegek törési felületein sûrú, kiválóan határozható vetőkarcos elmozdulási felületek láthatók (6. ábra).

A szelvény legtetején („C” rétegcsoport) 5-8 m vastag, szürkés drapp, rozsdabarna sávos agyagos aleurit, aleuritos agyag, finomhomokos aleuritrétegek (17. rétegcsoport) találhatók (3., 7. ábra), amelynek alsó részét, és kontaktusát a fekvő édesvízi mészkővel lejtőtörmelék fedi. A rétegsor középső részén két,hosszan és laposan ívelt, lencse alakú dolomitbreccsa réteg települ $30-40 \mathrm{~cm}$ legnagyobb vastagságban. A szemcsevázú kavicsos rétegek alsó és felső része éles, átmenet nélkül érintkezik a jóval finomabb szemcseméretú befoglaló üledékkel. A durva klasztok anyaga nagyrészt triász dolomit, amelyek általában nem, esetleg gyengén koptatottak, nagy részük éles, sarkos. A durva törmelékes rétegek kisebb részt 1-2 cmes jól kerekített kvarckavicsot és néhány más anyagú (pl. gneisz) kavicsot is tartalmaznak. Tömeges megjelenésük és üledékszerkezet nélküli, nagy méretú, lencsés rétegeik gyors, eseményszerú törmelékáthalmozódásra utalhatnak. A rétegsor felső szakaszán a durvatörmelékes rétegek vékonyabbak és sûrúbben települnek, míg végül a durva törmelékszemcsék csak elszórtan jelennek meg a finomszemcsés üledékben. A bánya É-i (meredeksége miatt megközelíthetetlen) falának szelvénye alapján a durvább törmelékes alsó szakaszt barna paleotalajos homokos lösz fedi. 


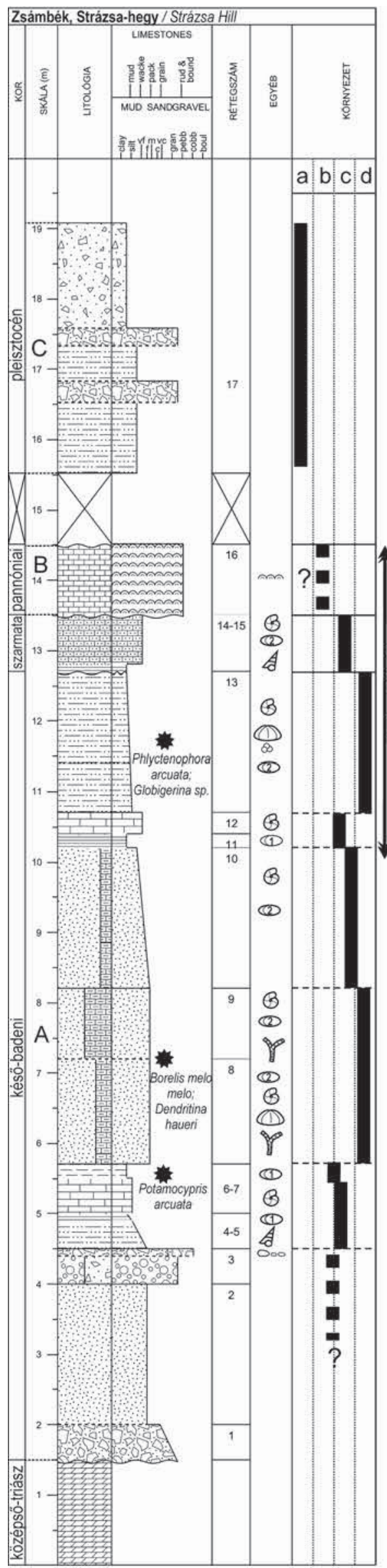

Litológia / lithology

F身 dolomit

m.

i. 0 breccia, sand

homok, homokkö sand, sandstone $\circ 0$
0
$\circ 0$

$\because$ közettörmelékes aleurit, homok s. silt, sand with rock debris

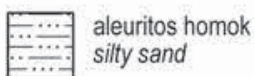

lemezes aleuritos agyag laminated silty clay

\section{품ㅁ mészkö}

돋미 limestone

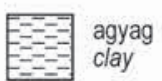

\section{폼ㅁㅁ homokos mészkö

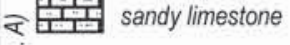

온 폳물 mésziszap

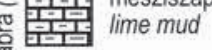

$<$

fontosabb kor vagy

környezetjelzö mikrofossziliák important environmental or age indicator microfossils
Szimbólumok/symbols

Rc fúrt abráziós kavicsok

Rs bored abrasional

Réteghatárok / boundaries

sharp

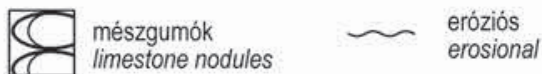

A $\begin{aligned} & \text { csiga } \\ & \text { gastropod }\end{aligned}$

(1) ostracoda (1-édesvizi, 2-tengeri)

echinodermata töredék echinoderm fragment

$m$ alga

bryozoa

(3) bentosz foraminifera

benthic foraminifers

8 plankton foraminifera

Környezet - environment

a - szárazföld - dry land

b - édesviz (tó) - freshwater (lake)

c - csökkent sós vizi lagúna, eusztárium, édesvizi hozzáfolyással csak a 7. rétegnél

shallow littoral lagoon with fluvial influx only layer 7

d - litorális, infralitorális, normálhoz közeli sótartalmú sekélytenger, háttér lagúna

litoral, infralitoral shallow marine, lagoon

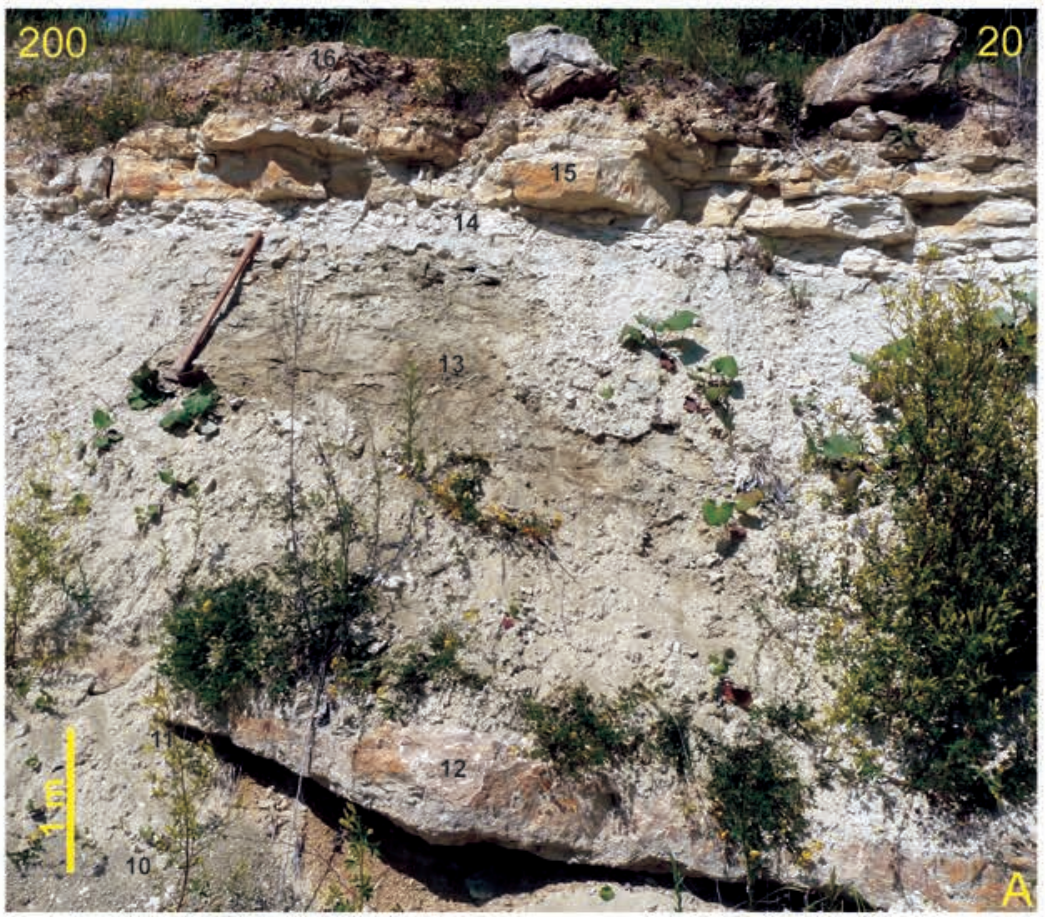

4. ábra. A strázsa-hegyi kőfejtő Ny-i falának rétegoszlopa a 12-16. réteg közeli fényképével (A) Figure 4. Stratigraphic column of the western wall of the Strázsa Hill quarry with detailed photo of layers $12-16(A)$ 


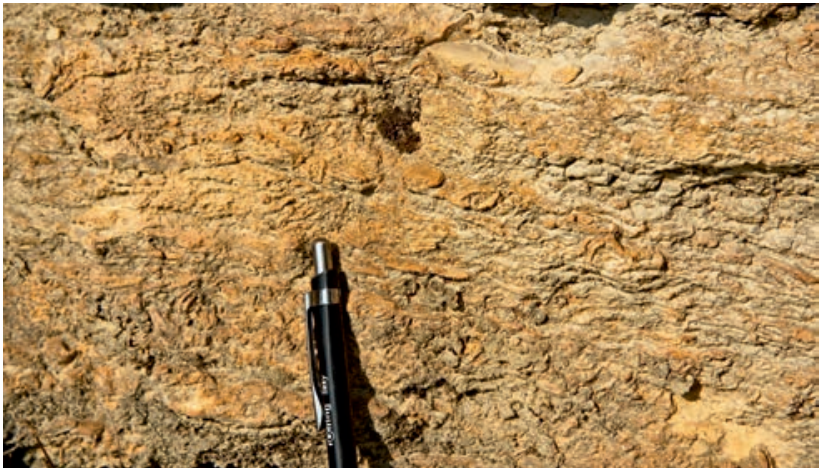

5. ábra. Onkoidos kifejlődésủ édesvízi mészkő (16. réteg)

Figure 5. Oncoidal freshwater limestone (bed 16)

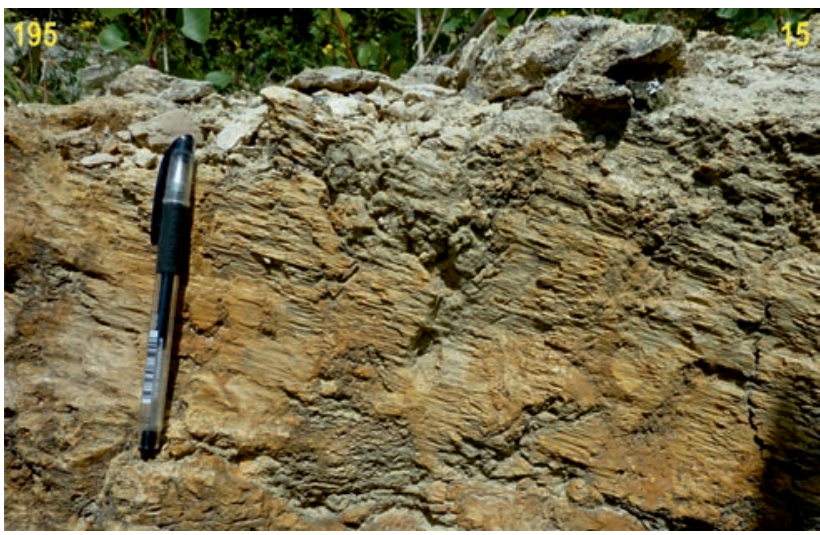

6. ábra. Balos eltolódásra utaló vetőkarcok a 16. réteg (édesvízi mészkő) oldalán Figure 6. Sinistral striae on freshwater limestone (bed 16)

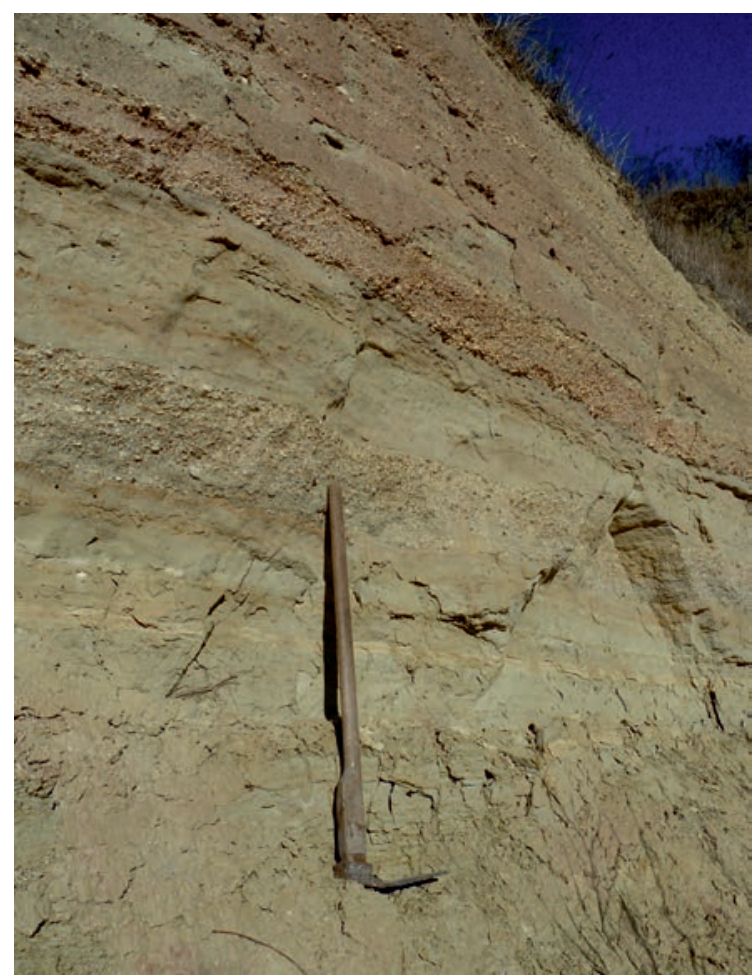

7. ábra. Törmeléklencsés homokos aleurit (pleisztocén alluviális-proluviális összlet) a Ny-i bányafal legfelső szakaszán

Figure 7. Sandy silt with debris-lenses (Pleistocene alluvial-proluvial sediment) forming the uppermost part of the western wall in the quarry

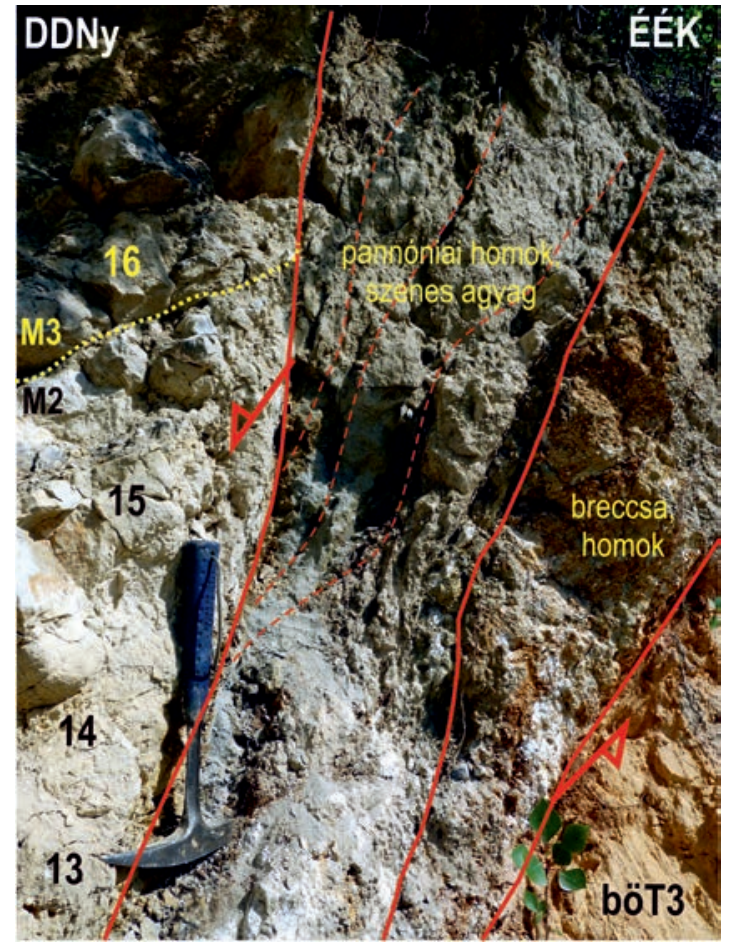

8. ábra. A miocén rétegsor (bal) és a triász dolomit (jobb) közé becsípődött pannóniai homok, agyag és dolomitbreccsa

Figure 8. Pannonian sand and clay in fault lens between the Miocene succession (left) and the Triassic dolomite (right)

„Szerkezeti zónába csípett képződmények”: A szelvény É-i részén található szerkezeti zónában (8. ábra) a miocén rétegsor, valamint a triász dolomit és dolomitbreccsa között, becsípett helyzetben olyan képződmények találhatók, amelyek a triászt fedő fiatal rétegsorból hiányoznak. A becsípett szakasz felfelé vastagodva 0,3-1,0 m vastagságban tárja fel az elmozdulási zónafelső szakaszán a triász dolomit mellé préselődő képződményt. A szerkezet alsó szakaszán az összetört triász dolomit erősen limonitos, dolomitporból és dolomitbreccsából álló képződménnyel érintkezik, amire szürke, szerves anyagban dús, lignites(?) agyag következik, amely tektonikusan érintkezik a miocén rétegsor meredeken dőlő rétegsorával. A felső szakaszon a 70-90-ban dőlő szerkezetekben szürke, jól osztályozott, középszemcsés kvarchomok, agyagos homok következik a szürke agyag és dolomitbreccsa egybepréselt képződményeire. A szürke homok szintén a miocén rétegsor elnyírt és meredeken dőlő rétegfejeivel érintkezik tektonikusan. A törés csapása a 16. rétegen észlelt vetőkarcos felületekkel közel párhuzamos.

\section{Óslénytani-rétegtani és mikrofácies vizsgálatok, képzôdési környezet}

A karbonátos, keményebb kőzetek vékonycsiszolatos, a laza törmelékes üledékek iszapolásos őslénytani vizsgálata alapján (II-III. táblázat) a rétegsor nagy része (1-13. réteg) 
II. táblázat. A Strázsa-hegy vizsgált rétegsorában előforduló foraminiferák

Table II. Stratigraphic ranges of foraminifers in the studied section of Strázsa Hill

\begin{tabular}{|c|c|c|c|c|c|c|c|c|c|c|c|c|c|c|c|c|c|c|c|c|c|c|c|c|c|c|c|c|c|}
\hline & & \multicolumn{28}{|c|}{ Foraminifera } \\
\hline 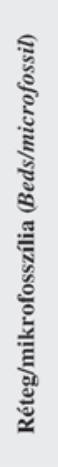 & 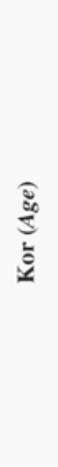 & 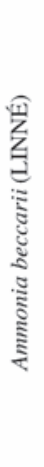 & 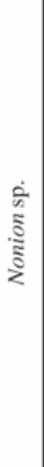 & 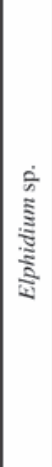 & 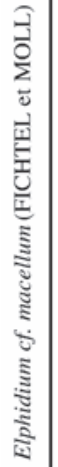 & 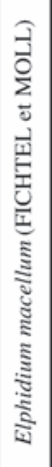 & 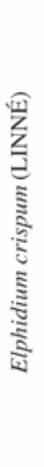 & 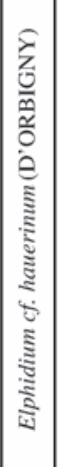 & 气ूँ & 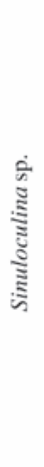 & 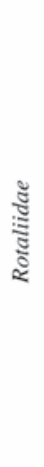 & 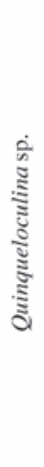 & 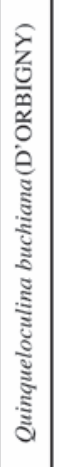 & 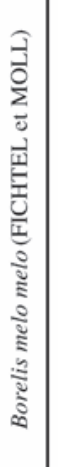 & 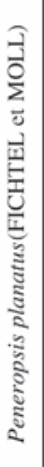 & 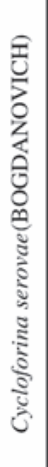 & 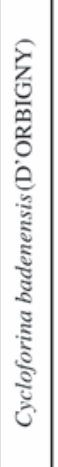 & 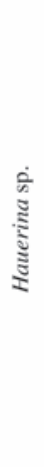 & 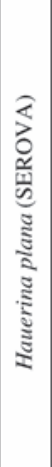 & 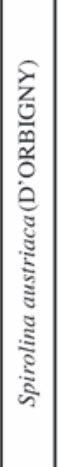 & 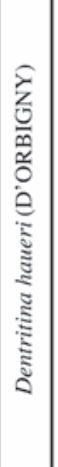 & 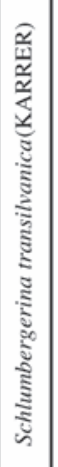 & 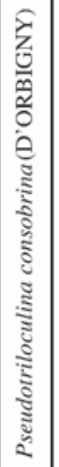 & 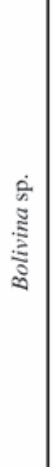 & 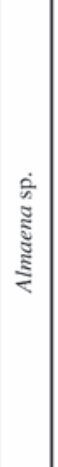 & 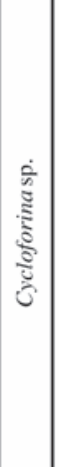 & 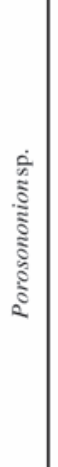 & 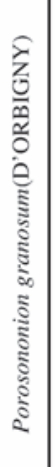 & 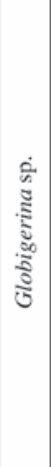 \\
\hline FZ2 & $\mathbf{P a}$ & $\mathrm{X}$ & & & $\mathrm{x}$ & & & $\mathrm{X}$ & & & & & & $\mathrm{X}$ & & & $\mathrm{x}$ & & & & & & & & & & $\mathrm{x}$ & & \\
\hline FZ1 & $\mathrm{Pa}$ & $\mathrm{X}$ & & & $\mathrm{x}$ & & & & & & & & & & & & & & & & & & & & & & & & \\
\hline 16 & $\mathbf{P a}$ & & & & & & & & & & & & & & & & & & & & & & & & & & & & \\
\hline 15 & Sża & & & & & $\mathrm{X}$ & & & $\mathrm{X}$ & $\mathrm{X}$ & $\mathrm{X}$ & & & & & & & & & & & & & & & & & & \\
\hline 13 & ปัँ & $\mathrm{X}$ & & & & $\mathrm{X}$ & & & & & & & & & & & & & & & & & & & & $\mathrm{x}$ & & $\mathrm{x}$ & $\mathrm{x}$ \\
\hline 12 & $\Xi$ & & & & & & & & & & & $\mathrm{X}$ & & & & & & & & & & & & & & & & & \\
\hline 10 & ฐั & $\mathrm{X}$ & & & & & & & $\mathrm{X}$ & & & $\mathrm{X}$ & & & & & & $\mathrm{X}$ & & & $\mathrm{x}$ & & & & & $\mathrm{x}$ & & & \\
\hline 9 & 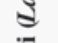 & $\mathrm{X}$ & $\mathrm{x}$ & & & $\mathrm{X}$ & $\mathrm{X}$ & & & & & $\mathrm{X}$ & $\mathrm{x}$ & $\mathrm{X}$ & $\mathrm{x}$ & $\mathrm{X}$ & & $\mathrm{X}$ & $\mathrm{X}$ & $\mathrm{X}$ & $\mathrm{x}$ & $\mathrm{x}$ & $\mathrm{x}$ & $\mathrm{x}$ & $\mathrm{x}$ & & & & \\
\hline 8 & हूँ & $\mathrm{X}$ & $\mathrm{X}$ & & $\mathrm{x}$ & & $\mathrm{X}$ & & & & & $\mathrm{X}$ & & $\mathrm{X}$ & $\mathrm{X}$ & $\mathrm{X}$ & & $\mathrm{X}$ & & & & & & & & & & & \\
\hline 7 & 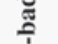 & $\mathrm{X}$ & & & $\mathrm{X}$ & & & & & & & & & & & & & & & & & & & & & & & & \\
\hline 6 & : & & $\mathrm{X}$ & & & & & & $\mathrm{X}$ & & & & & & & & & & & & & & & & & & & & \\
\hline 5 & ע & $\mathrm{X}$ & $X$ & $\mathrm{x}$ & & & & & & & & & & & & & & & & & & & & & & & & & \\
\hline
\end{tabular}

5-16: rétegszámozás, FZ1-2: szerkezeti zónába csípett rétegek, Sza - szarmata, Pa - pannóniai.

5-16: number of beds, FZ1-2: tectonically pinched layers, Sza-Sarmatian, Pa-Pannonian.

középsô-miocén, késô-badeni korú (4. ábra). A szelvény alsó szakaszában (5-6. réteg) csekély rétegtani értékú környezetjelző foraminiferák és ostracodák (Ammonia beccarii, Elphidium sp., Nonion sp.) találhatók, amelyek változó sótartalmú, inkább csökkent sós vízi sekély környezetet jeleznek. A tiszta, meszes üledékben visszatérő alak a lagúnák, eusztáriumok, deltakörnyezetek jellemző inbentosz formája, az Ammonia beccarii, amely szélsőséges környezeti ingadozásokat is eltûr (MURRAY 1973). Az ostracodás és bentosz foraminiferás wackestone mikrofáciesú kózet apró, már limonitosodott piritszemcsék és cementtel kitöltött üreges (vug), szemcseközi, esetleg kioldott szemcsék helyén képződött pórusokat tartalmaz (9. ábra A). A feltárás őslénytanilag legérdekesebb eredményét a 7. réteg faunája szolgáltatta. Ebben a rétegben a nagyon sekély, édesvízi környezetet jelzó ostracoda faj, a Potamocypris arcuata példányai uralkodtak az együttesben. A sekély folyóvizekben (patakok, kisebb vízfolyások) élő faj kizárólag kettós teknôvel történó megjelenése az üledékben gyors, hirtelen édesvízi hozzáfolyást jelez a sekélyvízi lagúna területére (MeIsch 2000). Az üledékből néhány csigaembrió és néhány halfog is elókerült. A nemzetközi és a hazai irodalomban felső-badeni rétegekbe történő édesvízi beömlés kimutatása nagyon ritka. Gross (2002) a Bécsi-medence badeni és szarmata rétegeinek ostracodáit taglaló munkájában is említ édesvízi taxonokat (Ilyocypris, Fabaeformiscandona, Pseudocythere), igaz kis példányszámban. Hazánkból ez- idáig egyetlen helyről, egy zsanai fúrás badeni rétegéből került elő édesvízi miocén ostracoda (SZuRominé \& CSEREPESNÉ 2013). Ebben a feltárásban nagy meglepetést okozva egy rétegben, dominánsan jelent meg egy édesvízi ostracoda faj (Potamocypris arcuata), ami valószínú, hogy lokális jelenségként értelmezhető.

A 8-9. réteg gazdag és különösen a 9. réteg diverz faunaegyüttesében a rétegre jellemző foraminifera, a Borelis melo melo mellett sztenohalin ostracodák (például Urocythereis kostelensis, Grinoides haidingeri) mellett az Elphidiumok és miliolidaek magas aránya arra enged következtetni, hogy a vízborítás sótartalma emelkedett a fekvő rétegéhez képest, de ingadozó, normálhoz közeli mértékú lehetett (Gross 2002, BETZLER \& SCHMitz 1997). Az ôsmaradvány-együttes növényzetben gazdag, jól szellőzött litorális, infralitorális, normálhoz közeli, ingadozó sótartalmú környezet jelez (GROss 2002). Az egykori környezet jellemzésére további adalékul szolgál a Borelis melo melo és a Dentritina haueri előfordulása is. BETZLER et al. (1997) szerint a BorelisesDendritinás közösségek a 20-40 m-es vízmélységú melegtengeri zátonyháttér lagúnákban, illetve zátonylejtő környezetekben élnek.

A Borelis tartalmú rétegre ismét nagyon rossz megtartású és szegényes, csökkent sós vízi faunaelemeket tartalmazó képződmények következnek (10-12. réteg), édesvízhez közeli karbonátképződéssel, ami a sótartalom csökkenésére utal. A rétegek ôsmaradvány-tartalma és környezete nagyon 
III. táblázat. A vizsgált rétegsorban előforduló ostracodák és egyéb fosszíliák

Table III. Stratigraphic ranges of ostracods and other fossils in the studied section of Strázsa Hill

\begin{tabular}{|c|c|c|c|c|c|c|c|c|c|c|c|c|c|c|c|c|c|c|c|c|c|c|c|c|c|c|c|c|}
\hline & & \multicolumn{21}{|c|}{ Ostracoda (Ostracods) } & \multicolumn{6}{|c|}{ Egyéb (Other fossils) } \\
\hline 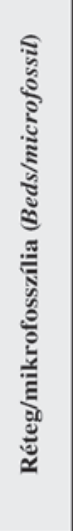 & 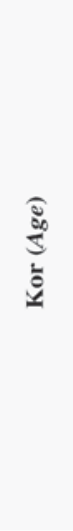 & 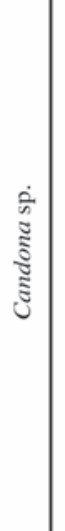 & 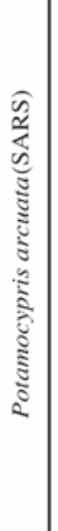 & 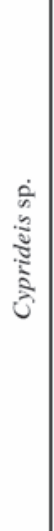 & 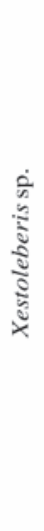 & 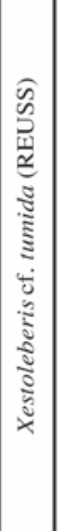 & 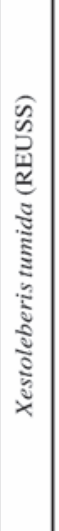 & 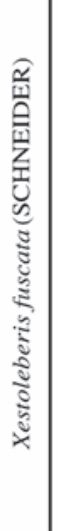 & 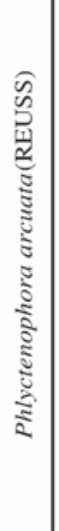 & 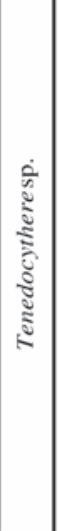 & 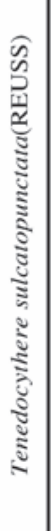 & 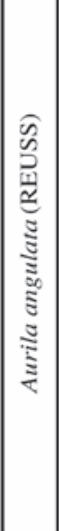 & 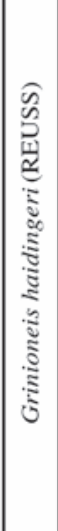 & 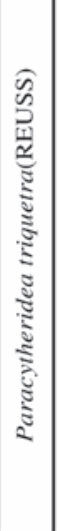 & 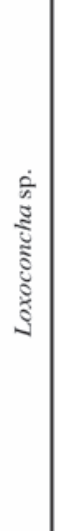 & 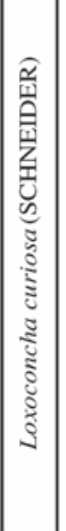 & 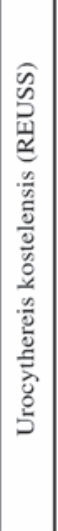 & 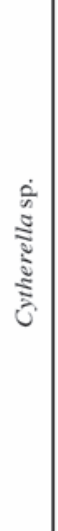 & 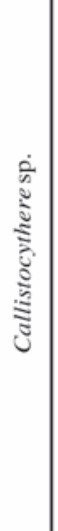 & 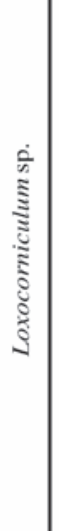 & 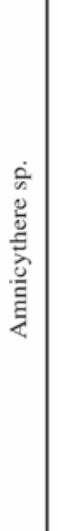 & & 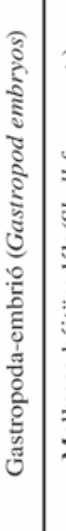 & 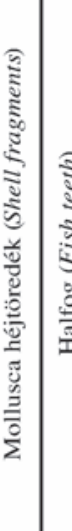 & 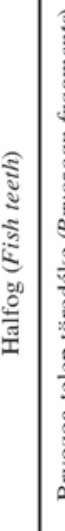 & 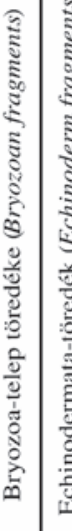 & | & 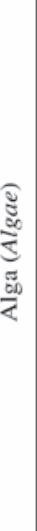 \\
\hline FZ2 & $\mathbf{P a}$ & & & & & & & & & & & & & & & & & & & & & & $\mathrm{X}$ & & & $\mathrm{X}$ & & \\
\hline FZ1 & $\mathbf{P a}$ & & & & & & & & & & & & & & & & & & & & & & & $\mathrm{X}$ & & & & \\
\hline 16 & $\mathbf{P a}$ & & & & & & & & & & & & & & & & & & & & & & & & & & & $\mathrm{X}$ \\
\hline 15 & $5 \bar{a}$ & & & & $\mathrm{X}$ & & & $\mathrm{X}$ & & & & & & & $\mathrm{X}$ & & & & & & & $\mathrm{X}$ & $\mathrm{X}$ & & & & & \\
\hline 13 & కี & & & $\mathrm{X}$ & & & & & $\mathrm{X}$ & \begin{tabular}{|l|}
$\mathrm{X}$ \\
\end{tabular} & & & & & $\mathrm{X}$ & & & & & $\mathrm{X}$ & $X$ & & & $X$ & & & $\bar{X}$ & \\
\hline 12 & ตับ & & & & & & & & & & & & & & & & & & & & & & & & & & & \\
\hline 10 & ฐั & & & $\mathrm{x}$ & & & $\mathrm{x}$ & & $\mathrm{x}$ & & & & & & & & & & & & & & & & & & & \\
\hline 9 & $\therefore$ & & & & & & $\mathrm{x}$ & & $\mathrm{x}$ & & $\mathrm{X}$ & $\mathrm{X}$ & $\mathrm{X}$ & $\mathrm{X}$ & & $\mathrm{X}$ & $\mathrm{X}$ & $\mathrm{x}$ & $\mathrm{x}$ & & & & $\mathrm{X}$ & & & \begin{tabular}{l|l}
$\mathrm{X}$ & $\mathrm{x}$ \\
\end{tabular} & $x$ & \\
\hline 8 & ت & & & & & $\mathrm{X}$ & & & & & & & & & & & & & & & & & & & & \begin{tabular}{l|l}
$X$ & $x$ \\
\end{tabular} & $\bar{X}$ & \\
\hline 7 & 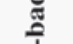 & $\mathrm{X}$ & $\mathrm{X}$ & $\mathrm{X}$ & & & & & & & & & & & & & & & & & & & $\mathrm{X}$ & & $\mathrm{X}$ & & & \\
\hline 6 & : & & & & & & & & & & & & & & & & & & & & & & & & & & & \\
\hline 5 & ฯ & $\mathrm{X}$ & & & & & & & & & & & & & & & & & & & & & & & & & & \\
\hline
\end{tabular}

5-16: rétegszámozás, FZ1-2: szerkezeti zónába csípett rétegek, Sza - szarmata, Pa - pannóniai.

5-16: number of beds, FZ1-2: tectonically pinched layers, Sza-Sarmatian, Pa-Pannonian.

hasonló a 3-6. rétegéhez. A törmelék beszállítódásának lecsökkenése ismét karbonátképződéshez vezetett, hasonlóan a 6. réteg képződése esetében. A 12. réteg mikroszkópi kőzetszövete erősen átkristályosodott szegényes bioklaszt tartalmú, peloidos mikrit, amelyet kioldott és zárt ostracodahéjak között megőrződött pórusok, valamint a pórusok falán fennőtt vékony drúzás cement jellemez (9. ábra B).

Az édesvízhez közeli, erôsen csökkent sós vízi rétegekre fokozatosan, de viszonylag vékony átmeneti kifejlődésen keresztül sekélytengeri, lagúna, normálhoz közeli ingadozó sótartalmú környezetben lerakódott réteg következik (13. réteg). A 13. réteget is felső-badeni korúnak tartjuk, a réteg faunaegyütteséből előkerült badeni korjelző Phlyctenophora arcuata faj (GROss 2002) és a Tenedocythere sp. néhány példánya alapján. A környezet korlátozott, esetleges nyílttengeri kapcsolatát feltételezhetjük a rétegsorban először megjelenő néhány Globigerina sp. példány alapján, amely a badeni kort is megerôsíti (9. ábra $C$ ). A finom, középszemú, karbonátos cementű homokkő szemcséi gyengén kerekítettek vagy szögletesek.

A késô-badeni rétegsor képződményeire diszkordánsan következő homokos mészkőben (15. réteg) jelentős változás figyelhetô meg a fauna összetételében. A finomhomokos, mikrites mészkő apró lukai (kipergett vagy kimállott $E l$ - phidium sp.) mellett csak néhány miliolidae és ostracoda jelenik meg. A szórtan megjelenő homoktartalmat az előzőhöz hasonlóan szögletes finom- és középszemú homok jellemzi kvarc- és csillámszemcsékkel. A homokos bioklasztos wackestone bioklasztjait nagyon szegényes, vékonyfalú mikrofosszília együttes, főként Nonion bogdanowiczi (9. ábra D), valamint Elphidium sp., Rotalidae- és Miliolida-félék példányai, továbbá néhány rossz megtartású ostracoda félteknő (Cytherois sp., Xestoleberis sp., Loxoconcha sp.) jellemzi. A szegényes és rossz megtartású ősmaradvány-együttesból már hiányoznak a badenire korlátozódó taxonok. Ezért és a mikrofosszília-együttes jellemzői alapján ezt a réteget már szarmatának tartjuk. Az üledékképződési környezet meleg, ingadozó sótartalmú (a normálnál kisebb sótartalmú) sekély (infralitorális) lagúna lehetett gazdag növényzettel (GöRöG 1992, TóTH 2009).

A szarmata mészkőre diszkordánsan települő édesvízi mészkőben (16. réteg) kizárólag algabekérgezések találhatók. A peloidos mikrit mátrixban vagy éles határvonal mentén elválasztott pátos cementben úszó $0,5-1 \mathrm{~cm}$-es kerekded vagy hosszúkás, bekérgező algák által körbevett klasztokból álló kőzet (9. ábra $E-F$ ) korjelző ősmaradványt ugyan nem tartalmaz, rétegtani helyzete azonban a környéken mélyült fúrások alapján rögzíthető. A Strázsa-hegyen ismert édes- 

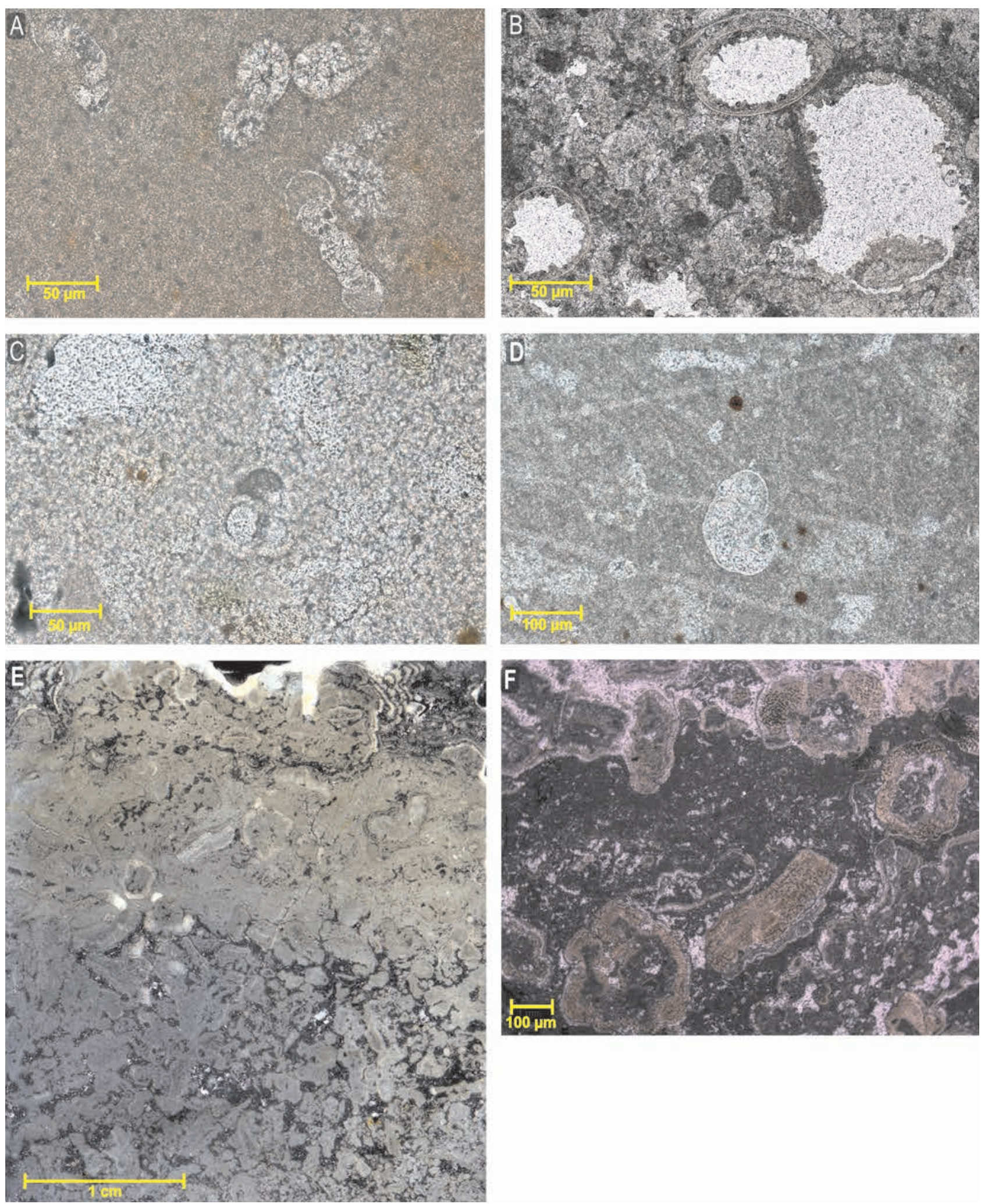

9. ábra. Mikrofáciesek és jellemző ősmaradványok a Strázsa-hegy miocén rétegsorából

A) ostracoda, bentosz foraminifera (Foraminifera indet.) wackestone (6. réteg), B) átkristályosodott peloidos mikrit, kioldott ostracoda üregében növekvő drúzás kalcittal (12. réteg), C) késö-badeni karbonátos cementủ homokkő plankton foraminiferával (13. réteg), D) szarmata homokos, bioklasztos wackestone, Nonion bogdanowiczi (15. réteg), E) pannóniai algabekérgezéses édesvízi mészkő felületi csiszolata (16. réteg), F) peloidos mikritcementben úszó, algákkal bekérgezett kerekded és hosszúkás szemcsék pannóniai édesvízi mészköben (16. réteg)

Figure 9. Microfacies and specific microfossils from the Miocene beds of Strázsa Hill

A) ostracod and benthic foraminifers (Foraminifera indet.) wackestone (bed 6), B) recrystallized peloidal micrite with growing druse calcite in dissolved ostracod vugs (bed 12), C) Late Badenian carbonate-cemented sandstone with planktonic foraminifer (bed 13), D) Sarmatian sandy bioclastic wackestone, Nonion bogdanowiczi (bed 15), E) polished surface of Pannonian freshwater limestone with algae crusting (bed 16), F) roundish and long-shaped, algae crusted clasts in peloidal micrite of Pannonian freshwater limestone (bed 16). 
vízi mészkőhöz hasonló kifejlődést JÁMBOR (1980a) említett betelepülésként a Zsámbéki-medence néhány fúrásából (Zsámbék Zst-3, -4, Mány Má-191) az ooidos szarmata mészkő (Tinnyei F.) és a fölötte települő, túlnyomó részben márgából álló pannóniai rétegsor határáról. Ezeket a tömör „pizolitos” mészköveket sekély tavak üledékének minősítette (JÁMBOR 1980b), és később a Csákvári Formációba (Strázsahegyi Mészkő Tagozat) sorolta (JÁMBOR 1996b). A Strázsa-hegyen a pannóniai rétegsor fiatalabb, agyagmárgából álló szakasza azonban lepusztult vagy csak részben ülepedett le, így az édesvízi mészkőre kvarter üledékek települnek.

A rétegsort fedő törmelékes üledék (17. réteg) ősmaradvány-mentes. Kőzettani összetétele és települési helyzete alapján feltételezhetôen a területen található negyedidőszaki rétegsor alsó részét képviseli. Képződése jelentős törmelék-lehordással jellemezhető időszakos, széles kiterjedésú vízfolyásokhoz köthető, amelyek a szerkezeti zóna által preformált paleofelszín mélyedéseiben haladtak, azt erodálták, és időszakosan nagy mennyiségú durva törmeléket szállítottak.

A szerkezeti zónába csípett rétegek sokszor erősen koptatott, sérült, minden bizonnyal az ismertetett rétegsorból származó áthalmozott badeni és szarmata foraminiferákat és ostracodákat tartalmaznak. A becsípett szakasz alsó, agyagosabb felében található Cyprideis-félék nagyon hasonlóak a „globigerinás, homokos márga”-ban (15. réteg) megfigyelt ostracodákhoz, így azok áthalmozottak is lehetnek. Hasonlóképpen, a felső, homokos képződmények Borelis sp. és bryozoa teleptöredékek koptatott példányai a 8-9. rétegek ősmaradványainak áthalmozott példányai lehetnek. Az áthalmozódást erősíti, hogy a faunaelemek a lepusztulás sorrendjében, rétegtanilag fordítva jelennek meg. Egyéb mikrofosszília nem található ezekben a rétegekben. A szerkezeti zónába csípett képződmények korát a mikrofosszíliák áthalmozott jellege középső-miocénnél fiatalabbnak, települési helyzetük pedig a negyedidőszaki réetgsornál idősebbnek jelöli ki. Kőzettani jellegeik szerint a lignites, magas növényi szervesanyag-tartalmú agyagos üledékek, és a náluk fiatalabb, ősmaradványmentes, jól osztályozott kvarchomok a késő-miocén (pannóniai) kort valószínúsíti. Ezt támasztja alá, hogy a Strázsa-hegy környékén mélyült fúrások pannóniai rétegsorában szintén előfordulnak szenes agyagos képződmények, hasonlóan a gerecsei Vályús-kút Csákvári Formációba sorolt rétegsorához (MAGYAR et al. 2017; SzTANÓ et al. 2018). A tavi, mocsári rétegek képződése a szerkezeti zóna múködésével közel egyidős, esetleg annál kissé idősebb lehetett, és megőrződésük is ennek köszönhető.

\section{A Strázsa-hegy kainozoos rétegsorának szerkezeti adatai és értelmezésük}

A strázsa-hegyi kőfejtő Ny-i fejtési szakaszán általunk részletesen vizsgált, ÉÉK-DDNy-i lefutású szelvényben (3. ábra) jó feltártsági viszonyok között tanulmányozható a fent ismertetett felső-badeni-szarmata-pannónai rétegsor és a triász dolomit tektonikus érintkezése (8. ábra). A szelvény É-i oldalán, a triászhoz képest magasabb topográfiai helyzetben, a szerkezeti zóna kivetített vonalának látszólag ellentétes oldalain található miocén és pleisztocén képződmények kontaktusa a lefedettség miatt nem vizsgálható, így nem határozható meg a szerkezet legfiatalabb aktivitása sem. A bánya K-i bejáratánál lévő bányafalon látható, eróziós felszínnel települő pleisztocén rétegsor alapján azonban feltételezhető, hogy a negyedidőszaki rétegsor itt is eróziós diszkordanciával (csatorna, eróziós vályú) települ az idősebb képződményekre, nagy valószínúséggel lefedve a szerkezeti zónát is.

A miocén rétegsorban mért rétegdőlésértékek átlagosan 314/13-os értéket adnak (10. ábra). Ez némileg ellentmond a Zsámbéki-medence K-i, DK-i átlagos dőlésirányainak (JASKÓ 1943a, b; FODOR et al. 2000; PALOTÁs 2014), ennek oka a szerkezeti zóna közelsége lehet. A tektonikus érintke-

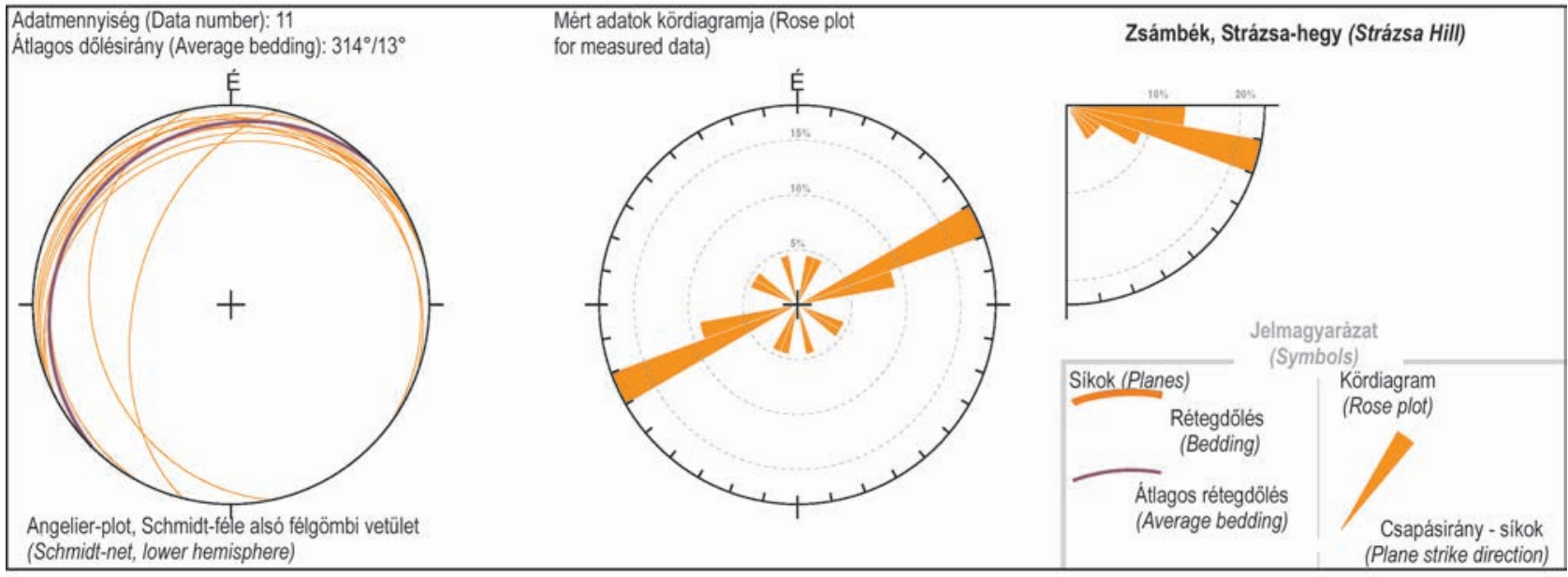

10. ábra. A zsámbéki Strázsa-hegyi kőfejtőben mért miocén rétegdőlésadatok sztereogramja és a rétegdőlés adatokhoz rendelt csapáseloszlás rózsadiagramja (Schmidt-féle alsó félgömb vetület)

Figure 10. Stereogram of measured dip directions of Miocene beds from the Strázsa Hill quarry at Zsámbék and rose diagram showing the frequency distributions of the azimuts of dip direction data (Schmidt lower-hemisphere projection) 
zés fő síkjához közeledve a meredekebb, 30-50 közötti, Ny-i dőlésirányú értékek jellemzőek. Az erôsen összetört triász dolomit rétegdőlés-értékeit ezen a falszakaszon nem sikerült rögzítenünk.

A vizsgált szelvényben a triász és a miocén rétegsor kontaktusa a szelvény az É-i részén tektonikus, a középső és D-i szakaszon üledékes, ahol kis méretú feltolódások léptetik el a határt. A miocén rétegsort É-i és D-i lefutású meredek vetô mentén a fiatal rétegsorral érintkezô triász dolomitos rétegek takarják. A fal meredeksége miatt a D-i szakaszon ez csak feltételezhetően, az É-i szakaszon azonban igazolhatóan enyhe feltolódásos szerkezetként jelenik meg (8. ábra). A miocén rétegösszletben észlelt törések jelentős részén balos oldaleltolódásos karcokat mértünk (11. ábra), melyek túlnyomó többsége a 16. réteghez kötődik (6. ábra). Az eltolódás mentén a triász dolomit enyhén rátolódva deformálta a miocén rétegsort. A vizsgált falszakaszon mért töréses szerkezeti adatok alapján számolt feszültségtér megközelítőleg É-D (ÉÉNy-DDK) irányú összenyomást valószínúsít (11. ábra A) a legfiatalabb érintett üledékes képződmények (16. réteg) leülepedését követő időszakra vonatkozóan.

A mért miocén rétegdőlések átlagával visszabillentett töréses adatok is megközelítőleg É-D-i kompressziót jeleznek (11. ábra B), mely néhány fok eltérést jelent csak a jelenleg tanulmányozható geometriai viszonyokhoz képest. Ez alapvetően a közel É-D csapású vetősíkok ÉNy-i és Ny-i irányba történt kismértékú kibillentésének köszönhető. A középső-miocén képződmények leülepedését követô billenés jellege, oka és területi kiterjedése jelenleg nem tisztázott (szinszediment szerkezetalakulás, posztszediment tektonika). A csekély mennyiségú, túlnyomó többségében a töréses szerkezetek közvetlen közelében mért, az átlag ÉNy-i dőlésiránytól eltérő, Ny-i irányú és a többséghez viszonyítva meredek (cca. $40^{\circ}$ ) rétegdőlések egyik kiváltó oka maga a szerkezeti zóna múködése lehetett. A lokális anomális rétegdőlés és az enyhe kompresszió hatására az oldalelmozdulás két oldalán elhelyezkedő képződmények jelentős kőzetfizikai különbözőségéből fakadóan, a kompakt triász dolomit elvonszolta és enyhén felgyưrte a gyengén kon-

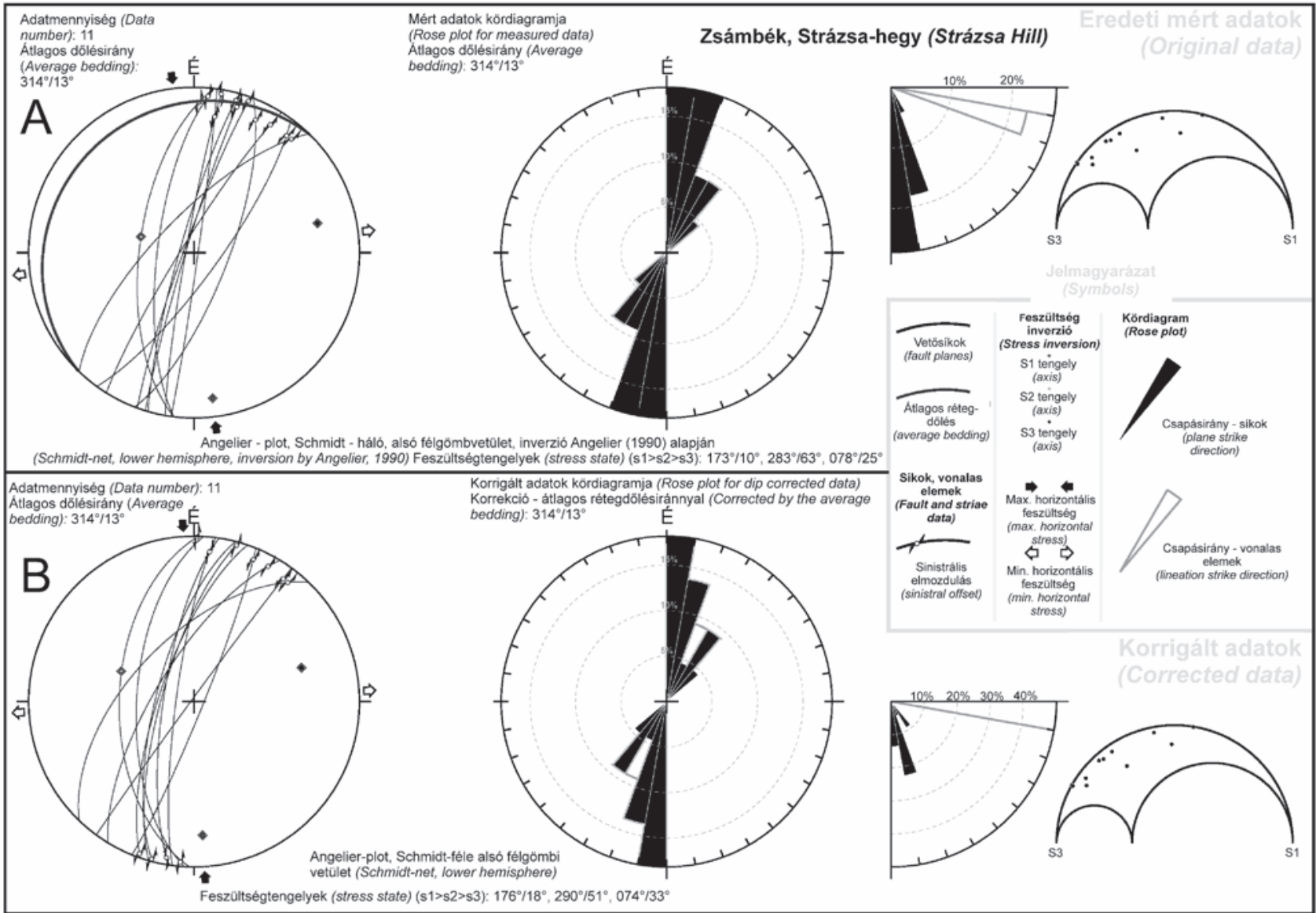

11. ábra. A zsámbéki Strázsa-hegyi kőfejtőben mért szerkezeti adatok. A) A miocén rétegösszletben mért törések és az azok menti elmozdulást jelző vetőkarcok ábrázolása sztereografikus projekción, töréssíkadatokhoz rendelt csapáseloszlás rózsadiagramja. B) Az átlagos miocén rétegdőléssel $\left(314^{\circ} / 13^{\circ}\right)$ visszabillentett miocén rétegösszletben mért törések és az azok menti elmozdulást jelző vetökarcok ábrázolása sztereografikus projekción, töréssíkadatokhoz rendelt csapáseloszlás rózsadiagramja (Schmidt-féle alsó félgömb vetület)

Figure 11. The measured main structural dataset of the Zsámbék Strázsa Hill quarry. A) Stereographic projection of faults, fractures, joints with related linear structures (slickenside, striae, pitch) in Miocene beds and the rose diagram of the frequency distributions of brittle tectonic structures. (Schmidt lower-hemisphere projection.) B) Stereographic projection of faults, fractures, joints with related linear structures (slickenside, striae, pitch) in Miocene beds after the correction by average Miocene bedding $\left(314^{\circ} / 13^{\circ}\right)$ and the rose diagram of the frequency distributions of brittle tectonic structure. (Schmidt lower-hemisphere projection) 
szolidált miocén üledékeket. Ezt erősíti meg a dolomit és a miocén üledékek kontaktusára jellemzô, virágszerkezetre emlékeztető zóna, amelyek törésiránya egybeesik a tisztán eltolódásos karcokat létrehozó szerkezettel.

Igazolhatóan szinszediment szerkezeteket nem sikerült észlelni a szelvényben, azonban a rétegsor 6-9. rétegeinek rálapolódása a fekvő rétegekre és ezek ÉÉK-i irányú vastagodása (3. ábra) látszólag É felé dőlő félárokszerkezetre utal. Azonban ha figyelembe vesszük az ÉNy-i rétegdőlés adatait és a szelvény irányát (ÉÉK-DDNy), akkor érthetô, hogy a rétegsor közel csapásirányú metszetének rétegszerkezetét látjuk, és a rétegsor vastagságát befolyásoló esetleges tektonikai szerkezetet az elbányászott DK-i részen (éppen a prekainozoos aljzatban észlelt rátolódás zónájában) kellene keresnünk. Feltételezhető azonban, hogy különösen a rétegsor alsó részén található durvatörmelékes, helyi anyagú, kis szállítást szenvedett triász klasztokból álló breccsa szinszediment tektonikai esemény következtében rakódott le. Ezt igazolják a szelvény D-i részén, a triász aljzatban látható kisebb feltolódások, melyek mentén a triász dolomit részben rátolódik a középső-miocén (badeni) rétegekre, részben azokkal fedett (3. ábra). A kis feltolódott blokkok tetejéhez futnak ki a fent említett breccsarétegek. Ez a késő-badeni szinszediment szerkezetalakulás tehát megelőzi a teljes rétegsort átmetsző, a miocén és a triász rétegsort egymás mellé hozó, fiatalabb transzpressziós deformációt, és egyben enyhén redőzi, illetve kibillenti a már lerakódott rétegsort.

\section{Diszkusszió}

A Strázsa-hegy kőfejtője feltárja a Vértessomló-Nagykovácsi-zónát, amelynek mentén a medencealjzatot alkotó nori Fődolomitra D-i vergenciával rátolódott a ladin-karni összlet (BUDAI et al. 2015). Az általunk vizsgált késő-badeni-szarmata-kora-pannóniai rétegsorban a legidősebb észlelt szerkezetek a késô-badeni sziliciklasztos rétegsor leülepedésével egyidős feltolódások (3. ábra), amelynek mentén a triász dolomit kismértékben rátolódott a miocén képződményekre, miközben a morfológiailag kimagasodó felszínérôl lepusztult triász törmelék breccsarétegként jelentkezik a miocén üledékben. A breccsát tartalmazó rétegek felső részén jelentkező bioperforált, abráziós parti kavicsok a rétegsor leülepedésével egyidős, közeli sziklás tengerparti környezetből származhattak, ennek helyzete azonban jelenleg nem ismert. A fúrt klasztok rétegszerú megjelenése (3. réteg) alapján feltételezhetô, hogy azok nagyobb energiájú üledékszállítás során (pl. cunami) rakódtak le, amely összhangban van az észlelt szinszediment tektonikai eseménynyel. A feltehetóen kompressziós vagy transzpressziós (a fal meredeksége miatt mérések hiányában azonban nem igazolható) esemény következtében a miocén rétegsor kissé kibillent, ami a badeni rétegsor rálapolódását eredményezte a kibillentett felszínre. Ez ellentmondani látszik a Gerecsében kimutatott, és általában jellemző középső-miocén széthúzásos, D9-10-es (FodOR et al. 2018) feszültségmezőnek. Valószínúleg az ÉK-DNy-i széthúzásos feszültségmezőben job- bos eltolódásként felújuló Vértessomló-Nagykovácsi-zóna és a hozzá kapcsolódó, már létező (kora-miocén és paleogén deformáció) balos kiegészítő törései (ÉNy-DK-i törések) lokális kompressziós deformációja okozta a kismértékú badeni szinszediment rátolódásokat és a billentést. Másik megoldásként elképzelhető, hogy a Gerecsében kimutatott kora-miocén, közel ÉNy-DK irányú összenyomásos és rá merôleges széthúzásos feszültségtér (D8-as fázis, FoDOR et al. 2018) lokálisan később is aktív volt a Vértessomló-Nagykovácsi-zóna mentén. A szerkezeti zóna ilyen jellegú miocén felújulását már BALLA \& DuDKo (1989) is feltételezte. Ebben a lokális feszültségmezőben a Strázsa-hegyet metsző rátolódás is felújulhatott, helyi morfológiai kiemelkedést hozva létre a Zsámbéki-medence É-i részén, a badeni tenger partján vagy annak közelében. Ez részben magyarázhatja az anomális badeni és szarmata rétegdőlések megjelenését a vizsgált szelvényben.

A Zsámbéki-medence badeni partvidékéhez közeli morfológiai kiemelkedés egy, a Strázsa-hegytôl ÉNy-ra kialakult sekélyvizú lagúnát választott le a nyílt tengerről. A lagúna kapcsolatban lehetett a nyílt tengerrel, amelybe ugyanakkor viszonylag nagyobb mennyiségú édesvizet szállíthattak a vízfolyások. A mezozoos képződményekből álló sziget- vagy félszigetszerú szárazulat DK-i, nyílt tenger felé esô részén sziklás tengerparti környezet alakult ki, amelynek abráziós törmeléke megtalálható a háttérlagúna rétegsorában. Ez a törmelék nagyobb viharok, esetleg cunami(k) során kerülhetett a lagúna védettebb területére.

A Vértessomló-Nagykovácsi-zóna Strázsa-hegy környéki része a szarmata üledékképződés során (és talán még utána) is tektonikailag aktív morfológiai hát lehetett (hasonlóan az ún. „Etyeki-háthoz”, FoDOR et al. 2000) miközben az aktív normálvetôk mentén folyamatosan zajlott a részmedencék félárok szerkezetek menti süllyedése. A hát emelkedésére utal a szarmata összlet rendellenesen vékony kifejlődése és diszkordáns települése, illetve a fiatalabb képződmények teljes hiánya.

FODOR et al (2000) szerint a Zsámbéki-medencét meghatározó nagyobb szerkezetek kinematikai jellege és a feszültségtér elemzése alapján az ÉNy-DK és ÉÉNy-DDK irányú jobbos vagy jobbos-normál eltolódások, az É-D ÉK-DNy irányú törések normálvetôk vagy tenziós hasadékok, illetve a KÉK-NyDNy csapású balos eltolódások (,Etyeki-hát” szerkezetei) K-Ny-i, illetve DK-ÉNy-i húzásos feszültségmezóben keletkeztek és múködtek, amikor a maximális feszültségtengely csak ritkán volt vízszintes.

Véleményünk szerint a FODOR et al. (2000) által megállapított feszültségmező a Gerecséből kimutatott szerkezeti fázisok (FoDOR et al. 2018) közül a D10 és D12-es szarmatapliocén időszakra eső szerkezeti fázisoknak felel meg. FODOR et al. (2000) által a Zsámbéki-medencében vizsgált fő törések múködésének analógiája alapján, a gerecsei D10 és D12-es szerkezeti fázisnak (FODOR et al. 2018) megfelelően, a vizsgált területhez közeli fő peremtörések is feltehetően jobbos normál, a Vértessomló-Nagykovácsi-zónába eső szerkezetek pedig balos eltolódásként múködhettek a szarmata-pliocén során. A deformáció elemzésekor nem 
hagyhatjuk figyelmen kívül a Vértessomló-Nagykovácsi törészóna közvetlen közelségét, ezáltal a terület erőteljes szerkezeti preformáltságát, mely miatt a különböző feszültségmezőkben létrejövő deformációk az általánostól eltéró jellegeket is mutathatnak.

A badeni-szarmata, valamint a szarmata-pannóniai határon észlelt eróziós diszkordancia és a képződmények fáciesében mutatkozó jelentôs eltérés feltehetôen a terület kisebb szerkezeti emelkedésére és szárazra kerülésére utal, ami a rétegsorok részleges lepusztulására, esetleg a kifejlődés hiányára enged következtetni .

A fentebb bemutatott feszültségmező számítás (11. ábra) és a 16. (édesvízi mészkő) réteget szilárd, kôzetté vált állapotban ért deformáció, valamint a tektonikai szerkezetbe csípett üledékek őslénytani vizsgálata alapján egy ÉÉNy-DDK-i összenyomással jellemezhető transzpressziós feszültségmező hozta létre az ÉÉK-DDNy-i csapású balos eltolódást és az eltolódás mentén a triász képződmények kismértékú rátolódását a miocén rétegsorra. A deformáció kora biztosan szarmata utáni, ezt igazolja az édesvízi mészkő (16. réteg) rétegtani helyzete a pannóniai rétegsor alsó szakaszán. Ha ez a képződmény a szarmata végi regressziós ciklus (PALOTÁs 2014) záró tagja lenne, a kôzetté válást követó deformáció ebben az esetben is legfeljebb szarmata végi vagy kora-pannóniai korú lenne. Ezt támasztja alá a szerkezetbe csípett rétegek áthalmozott badeni és szarmata taxonokat tartalmazó kevert mikrofaunája és a környezó fúrásokban azonosított és a gerecsei Vályús-kútról leírt (SzTANó et al. 2018) pannóniai rétegek kózettani (szenes agyag, homok) jellege is. A szerkezeti zónába csípett pannóniai üledékek nem találhatók meg a Strázsa-hegy rétegsorában, tehát ezeknek a környékbeli fúrásokban észlelt települési helyzete alapján a pannóniai korú édesvízi mészkő és a rá eróziós diszkordanciával következő negyedidőszaki rétegsor képződése közötti időszakban kellett felhalmozódniuk és lepusztulniuk, valamint részben becsípődniük a tektonikai szerkezetbe. Az így kimutatott transzpressziós deformáció jól megfeleltethető a közeli Gerecséből leírt (FODOR et al. 2018) és deformáció szinten a Zsámbékimedencében eddig még nem észlelt D11-es deformációs fázisnak. VÉGHNÉ et al. (1978) közel Ny-K csapású, D-i vergenciájú, biztosan oligocén utáni rátolódásokat említ a Nagyegyháza-Csordakúti-medencéből. Fodor et al. (2018) szerint ezek az ÉÉNy-DDK-i összenyomásos feszültségtérben keletkezett rátolódások, továbbá a csordakúti külfejtésben észlelt NyÉNy-KDK csapású jobbos. valamint ÉÉKDDNy balos oldaleltolódások is feltehetôen ehhez a deformációs fázishoz tartozhatnak, amelynek a rövid idejú, epizodikus aktivitása a szarmata legvégére, esetleg a pannóniai legelejére eshet. Ebből az időszakból BADA (1994) is közel É-D-i kompressziós és erre meróleges tenziós feszültségteret határozott meg a Gerecse és az É-Zsámbéki-medence területéról.

A vizsgált területen a D11-es deformációs fázisnak megfeleltetett markáns balos oldaleltolódás és az ehhez kötődő transzpressziós szerkezetek kora a fentiek alapján a pannóniai elejére tehetô, esetleg annál kissé fiatalabb is lehet. A környékbeli fúrásokban megjelenő viszonylag vastag pannóniai rétegsor hiánya a szelvényben a terület pannóniai üledékképződésének hiányára, esetleg korlátozottságára (a terület részben kiemelt helyzetére) utalhat. Ezt támasztja alá KóKAY (1989) megfigyelése is, miszerint a Mány, Má-335 jelú fúrásban a szarmata-pannóniai határon gyökérzónához kötődő szárazföldi mészkonkréciós agyagos aleurit található, ami véleménye szerint a környék megemelkedését igazolja. Mindez jó összhangban lehet a vizsgált terület általunk feltételezett lokális emelkedésével, amelyhez hozzájárulhatott ebben az időszakban a Vértessomló-Nagykovácsi szerkezeti zóna DDK-i vergenciájú rátolódásos felújulása.

A szerkezeti fázis reaktiválhatta a fô szerkezeti zóna DDK-i vergenciájú rátolódásos komponenseit is, ami a terület lokális megemelkedésével és az addig lerakódott rétegek lepusztulásával járt.

A szerkezeti zóna legfiatalabb, negyedidőszaki aktivitását jelezheti a negyedidőszaki rétegsorban eseményszerúen megjelenő, a környék triász dolomitjából származó két viszonylag vastag breccsaréteg. A szerkezeti aktivitás pontos koráról egyelőre nincsenek adataink, annyi azonban bizonyos, hogy a kőfejtő K-i részén lévô szelvény barna erdôtalajos lösz rétegsorának képződését megelőző idôszakról lehet szó.

\section{Következtetések}

\section{Rétegtan}

A zsámbéki Strázsa-hegy kőfejtójében feltárt kainozoos rétegsor alsó, túlnyomó részben sziliciklasztos, karbonátos szakasza a felső-badeni és a szarmata emeletbe tartozik. A szarmata rétegsor rendellenesen vékony, alul és felül diszkordanciafelülettel határolt.

A középső-miocén rétegsorra diszkordánsan települő édesvízi onkoidos mészkő a Zsámbéki-medence felsô-miocén sziliciklasztos rétegsorának bázisképződményével azonosítható (Csákvári Formáció).

A rétegsor legfelső szakasza a pannóniai mészkốre diszkordánsan települő pleisztocén folyóvízi összlet a területen kifejlődött barna paleotalajos lösznél idősebb.

\section{Tektonika}

A vizsgált középsô-felsô-miocén és pleisztocén rétegsor a Vértessomló-Nagykovácsi-zóna zsámbéki felszíni kibukkanásának területén található, amelynek deformációja végig meghatározta a medencerész paleomorfológiáját és az üledékképződést. Ez magyarázza a területen mérhetô, az általános D-i, DK-i (Fodor et al. 2000, PALOTÁs 2014) iránytól eltérô, anomális ÉNy-i dőlésirányokat.

A legidősebb kainozoos szerkezeti elem a késő-badeni üledékekkel fedett rátolódásos szerkezet, amely enyhén redôzte és kibillentette az addig lerakódott rétegeket. A későbadeni szerkezetalakuláshoz breccsaképződés és feltehetően cunami jelenségek kapcsolódtak. Ezt a fázist a gerecsei 
D9-10-es (esetleg áthúzódó D8-as) szerkezeti fázisának feleltetjük meg. Attól eltérôen azonban a Vértessomló-Nagykovácsi-zóna menti deformációt nem húzás, hanem a jobbos eltolódás és a hozzá kapcsolódó balos kiegészítő törés közti deformációs tér lokális összenyomása határozta meg, ami a terület megemelkedését is eredményezte. Ennek okát a szerkezeti zóna zsámbéki szakaszának (elsôsorban késő-kréta és paleogén) tektonikai preformációjában látjuk.

A középső-miocénnél fiatalabb szerkezeti fázis biztosan a szarmata után, valószínúleg a kora-pannóniai során múködött. A feszültségtér-elemzés szerint ez a markáns, ÉÉK-DDNy csapású balos eltolódásban és ehhez kötődő rátolódásban jelentkező deformáció ÉÉNy-DDK-i transzpressziós feszültségtérben jött létre. A szerkezeti fázist a gerecsei D11-es fázissal azonosítjuk, amelyet erről a területről korábban még nem mutattak ki. Ennek a fázisnak a során került jelenlegi helyzetében egymás mellé a triász és a miocén rétegsor, és ekkor csípődött be a szerkezeti zónába a rétegsorból hiányzó pannóniai szenes agyagos és homokos képződmény.

A neotektonikai aktivitást jelzi a pleisztocén alluviálisproluviális összletben megjelenő durva hordalék, amely hirtelen és gyors szárazföldi törmelékbeszállítási eseményekre, és egyben a lepusztuló háttér tektonikus emelkedésre utal.

\section{Ösföldrajz, óskörnyezet}

A Zsámbéki-medence vizsgált területét a hazai viszonyok között is különleges üledékképződési környezet jellemezte a késő-badeni során, amelyet aktív szerkezetalakulás kontrollált. A Vértessomló-Nagykovácsi-szerkezet Strázsahegyen kibukkanó szakaszát a középső- és felső-miocén rétegsorok tanúsága szerint tektonikailag aktív paleomorfológiai kiemelkedésként értelmezhetjük ebben az időszakban. A morfológiai hát mögött, a badeni tenger partvidékén kezdetben változó, eleinte csökkent sótartalmú, sekély, partközeli védett lagúna jött létre, ahol jelentős volt a part menti törmelék beáramlása.

A sekélylagúna környezettel egyidős, annak közelében lévő abráziós sziklás partot valószínúsítünk a vizsgált szelvénytől D-re, a Vértessomló-Nagykovácsi-zóna rátolódási frontjának D-i részén. A szerkezeti zónát a védett lagúna és a sziklás parttal rendelkező nyílt tenger közötti paleomorfológiai hátként (szigetként vagy félszigetként) értelmezzük. A mögötte lévő védett öböl felfogta a szárazföld felől patakokkal, kisebb vízfolyásokkal érkezô törmeléket, amely ugyanakkor a nyílt tengerrel is kapcsolatba került időnként. Az epizodikusan behordódott, bioperforált abráziós parti kavicsok megjelenését földrengéshez kötődő, nagy energiájú árhullám (cunami) üledékeként értelmezzük. A szinszediment tektonikai aktivitás keltette árhullám a nyílt tenger felől (D-i irányból) átmosta a hullámverte abráziós terasz üledékét a paleomorfológiai magaslaton, amely ilyen módon kerülhetett a lagúna üledékei közé.
A késő-badeni során a vizsgált területet ingadozó sótartalmú, sekély lagúna borította. A feltárás érdekessége volt, hogy sikerült kimutatni a felső-badeni rétegekből édesvízi hozzáfolyást ostracoda-fauna alapján.

A felső-badeni rétegsorban két sótartalom változási ciklust tudtunk elkülöníteni. Az első ciklusban a csökkent sós vízi lagúnában fokozatosan egyre inkább normálhoz közeli sótartalmú környezet alakult ki (1-9. réteg), amelynek késôbb fokozatosan ismét csökkent a sótartalma (1012. réteg). Az ezt követô ciklus során a badeni üledékgyưjtő ismét normál sós közeli környezetté alakult, amely időszakosan kapcsolatba is kerülhetett a nyílt tengerrel (13. réteg). Ez feltehetően lokális szinszediment tektonikai eseményekre, illetve a medenceterület általános süllyedésére vezethetô vissza. A szerkezetileg aktív időszak után a lagúnába beömlő édesvíz hatására ismét megváltozott a környezet, amelynek egy újabb, az előzőnél jelentôsebb mértékú nyílt tengeri elöntés vetett véget a késő-badeni során.

A szarmata szerkezetalakulás során a rétegsor egy része bizonyosan lepusztult, ami a terület időszakos szárazulatra kerülését jelentette a badeni-szarmata határon.

A szarmatában ismét ingadozó, de a normálnál alacsonyabb sótartalmú lagúna környezetben zajlott az üledékképződés. A mikrofauna-együttes a korábbiakhoz képest jelentős mértékben elszegényedett.

A szarmata-pannóniai határon a terület ismét szárazra került és részleges lepusztulást szenvedett.

A pannóniai üledékképződés édesvízi tavi környezetben indult meg. A tavi algás mészkő képződését követően mocsaras, sekély vízi üledékképződési környezet jött létre a pannóniai során, amely feltöltődött. Eredeti vastagságáról nincsenek információink. A pannóniai képződmények jelenlegi rétegsorbeli hiányát a szerkezeti zóna területén a pannóniai során zajló szerkezetalakulási eseményhez (a terület emelkedéséhez) kötjük, és valószínúsítjük az üledékképződés korlátozottságát a környék azonos korú üledékgyűjtőihez képest.

A lösz lerakódását megelőző pleisztocén korszakot a felsőés középsô-miocén, illetve a triász képződmények részleges szárazföldi lepusztulása jellemezte. Az időszakos vízfolyások a denudációs felszín völgyeiben rakták le üledékeiket. Az uralkodóan finomszemcsés üledékben lencseszerúen lerakódott, triász kőzetekből származó durva törmelék a háttér időszakos, feltehetôen szerkezeti eseményekhez kötődő emelkedését jelzi.

\section{Köszönetnyilvánítás}

A dolgozat kéziratának alapos és konstruktív lektorálásáért a szerzők hálásak Kövér Szilviának és TóTH Emőkének, valamint SzTANó Orsolyának és FoDOR Lászlónak. Köszönjük a kőfejtőt üzemeltető KŐ-KER Csákvár Kft-nek a kutatáshoz való hozzájárulást. 


\section{Irodalom - References}

ANGELIER, J. 1990: Inversion of field data in fault tectonics to obtain the regionalstress III: A new rapid direct inversion method by analytical means. — Geophysical Journal International 103, 363-376 https://doi.org/10.1111/j.1365-246x.1990.tb01777.x

BADA G. 1994: A paleofeszültségtér fejlődése a Gerecse hegység és kelet-délkeleti előterének területén. — Kézirat, szakdolgozat, ELTE TTK Alkalmazott és Környezetföldtani Tanszék, Budapest, 137 p.

Bakony I., Németh A., PArtényi Z. \& Peregi Zs. 1977: A Dunántúli-középhegység földtani térképe, 20 000-es sorozat, Zsámbék. — Kézirat. Magyar Állami Földtani, Geofizikai és Bányászati Adattár.

BALlA, Z. \& DudKo, A. 1989: Large-scale Tertiary strike-slip displacements recorded in the structure of the Transdanubian Range. — Geophysical Transactions 35/1-2, 3-63.

BernhARDT B. \& InCZE Sz. 1998: Az Északkelet-Dunántúl oligocén képződményeinek litosztratigráfiai tagolása. — Kézirat, Magyar Állami Földtani, Geofizikai és Bányászati Adattár, Geokomplex Kft., Miskolc, J 502, 50 p.

Betzler, CH. \& Schmitz, St. 1997: First record of Borelis melo and Dendritina sp. in the Messinian of SE Spain (Cabo de Gata, Province Almeria). — Palaeontologische Zeitschrift 71/3-4, 211-216. https://doi.org/10.1007/bf02988489

BudAI T. 2004: Középső-triász medencefáciesek és vulkanitok a Zsámbéki-medencében. — A Magyar Állami Földtani Intézet Évi Jelentése 2002, 189-194.

Budai T., Fodor L. (szerk.), Császár G., Csillag G., Gál N., Kercsmár Zs. Kordos L., Pálfalvi S. \& Selmeczi I. 2008: A Vértes hegység földtana. Magyarázó a Vértes hegység földtani térképéhez (1:50 000). — Magyarország tájegységi térképsorozata, A Magyar Állami Földtani Intézet, Budapest, 368 p.

BudAi T., HaAs J. \& PIROS O. 2015: Új rétegtani adatok a Zsámbéki-medence triász aljzatából — szerkezetföldtani következtetések. — Földtani Közlöny 145/3, 247-257. https://ojs3.mtak.hu/index.php/foldtanikozlony/article/view/134

Cornée, J.-J., Moisette, P., Saint Martin, J.-P., Dulai, A., Tóth, E., Görög, Á., KÁzmÉr, M. \& Müller, P. 2009: Marine carbonate systems in the Sarmatian of the Central Paratethys: the Zsámbék Basin of Hungary. — Sedimentology 56, 1728-1750. https://doi.org/ 10.1111/j.1365-3091.2009.01055.x

Császár G., HaAs J. \& Jocháné EdelÉNyi E. 1978: A Dunántúli-középhegység bauxitföldtani térképe, M=1:100 000. — A Magyar Állami Földtani Intézet kiadványa, Budapest.

Csillag G. \& SzTanó O. 2015: Felső-miocén. In: Kercsmár Zs. (szerk.), Budai T., Csillag G., Selmeczi I. \& SzTANó O.: Magyarország felszíni képzôdményeinek földtana. Magyarázó Magyarország földtani térképéhez (1: 500 000). — Magyar Földtani és Geofizikai Intézet, Budapest, 42-46.

DunkL, I., FARICS, É., JózSA, S., LuKÁCs, R., HAAS, J. \& BudAI, T. 2019: Traces of Carnian volcanic activity in the Transdanubian Range, Hungary. — International Journal of Earth Sciences 108/5, 1451-1466. https://doi.org/10.1007/s00531-019-01714-w

FARICS É. 2018: A karni vulkanizmus nyomai a Dunántúli-középhegységben és a vulkanitok törmeléke a Budai-hegység eocén bázisképződményében. - Kézirat, PhD disszertáció, ELTE Általános és Alkalmazott Földtani Tanszék, 172 p.

FERENCZI I. 1923: A tinnyevidéki harmadkori medencerészlet földtani viszonyai. (Jelentés az 1919-20. évi felvételi munkákról.) — A Magyar Királyi Földtani Intézet Évi Jelentése 1920-23, 40-49.

FODOR L. 2008: Szerkezetföldtan. — In: BudAI T. \& FodOR L. szerk. 2008: A Vértes hegység földtana. Magyar Állami Földtani Intézet, Budapest, 145-202.

FODOR L. \& BíRó I. 2004: Eocén sziklás tengerpart a vértessomlói kréta rátolódás mentén (Szarvas-kút, Vértes). — A Magyar Állami Földtani Intézet Évi Jelentése 2002, 153-62.

Fodor L., Magyari Á., Fogarasi A. \& PALOtÁs K. 1994: Tercier szerkezetfejlődés és késő paleogén üledékképződés a Budaihegységben. A Budai vonal új értelmezése. — Földtani Közlöny 124/2, 129-305.

Fodor L., Lelkes Gy., Müller P. \& PAlotás K. 2000: Előzetes jelentés a Budai hg. - Gerecse hg. - Vértes hg. közötti terület badeni és szarmata ősfödrajzi, szin- és poszttektonikai viszonyairól. — Kézirat. Magyar Állami Földtani Intézet, 19 p.

Fodor L., Bíró I., Albert G. \& LANTOs Z. 2005: New structural observatoins along the Vértessomló Line and implications for structural evolution of the Transdanubian Range (western Hungary). — Geolines 19, 38-40.

Fodor L., Kercsmár Zs. \& KövÉr Sz. 2018: A Gerecse szerkezete és deformációs fázisai. — In: BudAI T. (szerk.): A Gerecse hegység földtana. Magyar Bányászati és Földtani Szolgálat, Budapest, 169-207.

GIDAI L. 1979: Az eocén kőszén kutatási lehetőségei a Mány-Zsámbék közötti területen. — Bányászati és Kohászati Lapok, Bányászat 112/4, 268-271.

GöröG, Á. 1992: Sarmatian foraminifera fauna of the Zsámbék Basin, Hungary. — Annales Universitatis Scientiarum Budapestinensis de Rolando Eotvos Nominatae, Sectio Geologica 29, 31-153.

Gross, M. 2002: Mittelmiozäne Ostracoden aus dem Wiener Becken (Badenium/Sarmatium, Österreich)/Middle Miocene Ostracods from the Vienna Basin (Badenian/Sarmatian, Austria). — Unpublished thesis, Karl-Franzens Universitat Graz, 1-149.

GYALOG L. (szerk.) 1996: A földtani térképek jelkulcsa és a rétegtani egységek rövid leírása. — A Magyar Állami Földtani Intézet Alkalmi Kiadványa 187, 171 p.

GyAlog L. \& BudAI T. (szerk.) 2004: Javaslatok Magyarország földtani képződményeinek litosztratigráfiai tagolására. — A Magyar Állami Földtani Intézet Évi Jelentése 2002, 195-232.

Halaváts Gy. 1892: A herczeghalmi artézi kút. — Földtani Közlöny 22/5-6, 163-169.

HaAs J., Budai T., Csontos L., Fodor L. \& Konrád Gy. 2010: Magyarország pre-kainozoos földtani térképe, 1:500 000. (Pre-Cenozoic geological map of Hungary, 1:500000.) — A Magyar Állami Földtani Intézet kiadványa, Budapest. (In Hungarian and in English)

HantKen M. 1861: Geologiai tanulmányok Buda s Tata között. — Mathematikai és Természettudományi Közlemények 1, 213-278.

JÁMBOR Á. 1967: Adatok a Zsámbéki- és a Mányi-medence Neogénjének ismeretéhez. — Kézirat, Magyar Állami Földtani, Geofizikai és Bányászati Adattár, Budapest. 
JÁMBOR Á. 1969: A Budapest környéki neogén képződmények ősföldrajzi vizsgálata. — A Magyar Állami Földtani Intézet Évi Jelentése 1967-ról, 135-142.

JÁMBor Á. 1975a: A budajenői Bő-2. sz. fúrás kvarter és neogén képződményeinek rétegsora. — Kézirat, Magyar Állami Földtani, Geofizikai és Bányászati Adattár, Budapest

JÁMBOR Á. 1975b: A Zsámbéki-medencei szarmata kénelőfordulás kutatási terve. — Kézirat, Magyar Állami Földtani, Geofizikai és Bányászati Adattár, T.5294, 63 p.

JÁMBOR Á. 1976: Üledékes kéntelep a Zsámbéki-medence szarmata sorozatában. — A Magyar Állami Földtani Intézet Évi Jelentése 1974-ról, 301-306.

JÁMBOR Á. 1977: A mányi-medence neogén képződményei felépítésének vázlata. — Földtani Kutatás 20/4, 25-27.

JÁMBOR Á. 1978: Új elképzelések a magyarországi neogén tengerek vizének sótartalom-változásairól. — A Magyar Állami Földtani Intézet Évi Jelentése 1976-ról, 261-265.

JÁMBOR Á. 1980a: A zsámbéki 1: 20 000-es térképlap oligocén, neogén és kvarter képződményeinek földtani jellemzése. — Kézirat, Magyar Állami Földtani, Geofizikai és Bányászati Adattár, Budapest.

JÁMBOR Á. 1980b: Szigethegységeink és környezetük pannóniai képződményeinek fáciestípusai és ősföldrajzi jelentőségük. — Földtani Közlöny 110/3-4, 498-511.

JÁMBOR Á. 1988: A magyarországi pannóniai (s.l.) képződmények geológiája. — A Magyar Állami Földtani Intézet, Budapest, 52 p.

JÁMBOR Á. 1996a: Perbáli Formáció. — In: GYAlog L. (szerk.): A földtani térképek jelkulcsa és a rétegtani egységek rövid leírása. — A Magyar Állami Földtani Intézet Alkalmi Kiadványa 187, p. 82.

JÁMBOR Á. 1996b: Zsámbéki Márga Formáció. In: GYALOG L. szerk.: A földtani térképek jelkulcsa és a rétegtani egységek rövid leírása. - A Magyar Állami Földtani Intézet Alkalmi Kiadványa 187, 75-76.

JÁmbor Á., KóKAY J., Lelkes Gy., SelmeCZi I. \& Szegó É. 2003: A Mányi-medence neogénjének újabb vizsgálati eredményei. — 6. Magyar Öslénytani Vándorgyúlés, 2003. május 8-10, Zirc. Program, elôadáskivonatok, kirándulásvezetô, 15-16.

JASKó S. 1943a: Adatok a Bicskei neogén öböl földtani ismeretéhez - A Magyar Királyi Földtani Intézet Évi Jelentése 1939-40-ról (I), 335-359.

JASKÓ S. 1943b: A Bicskei-öböl fejlődéstörténete, hegyszerkezete és fúrásai. — Beszámoló a Magyar Királyi Földtani Intézet Vitaüléseinek Munkálatairól. A Magyar Királyi Földtani Intézet 1943. Évi Jelentésének Függeléke 5, 254-302.

KerCsMÁr Zs. 2004: A tatabányai vöröskalcittelérek szerkezetföldtani jelentősége. — A Magyar Állami Földtani Intézet Évi Jelentése 2002, 163-174.

KerCSMÁr Zs. 2005: A Tatabányai Eocén Medence földtani felépítésének és fejlődéstörténetének újabb kutatási eredményei, üledékföldtani és tektono-szedimentológiai vizsgálatok alapján. — Kézirat, PhD thesis, Eötvös Loránd Tudományegyetem Természettudományi Kar, Ôslénytani Tanszék, 173 p.

Kercsmár Zs. (szerk.), Budai T., Csillag G., Selmeczi I. \& SzTanó O. 2015: Magyarország felszíni képzödményeinek földtana. Magyarázó „Magyarország felszíni földtani térképéhez” (1:500 000). — Magyar Földtani és Geofizikai Intézet, Budapest, 62 p.

KóKAY J. 1989: A mány-zsámbéki terület badeni és szarmata képződményei. — Kézirat, Magyar Állami Földtani, Geofizikai és Bányászati Adattár, Budapest, T15021, 27 p.

LIFFA A. 1905: Agrogeológiai jegyzetek Tinnye és Perbál vidékéról. — A Magyar Királyi Földtani Intézet Évi Jelentése 1904, $227-251$.

MaGYAR I. 2010: A Pannon-medence ösföldrajza és környezeti viszonyai a késó miocénben. — Geolitera, Szeged, 140 p.

Magyar I., Sztanó O., Csillag G., Kercsmár Zs., Katona L., Lantos Z., Bartha I. R. \& Fodor L. 2017: A Gerecse pannóniai puhatestûi és lelőhelyeik: rétegtan, őskörnyezet és fejlődéstörténet (Pannonian molluscs and their localities in the Gerecse Hills, Transdanubian Range). — Földtani Közlöny 147/2, 149-176. https://doi.org/10.23928/foldt.kozl.2017.147.2.149

Maros Gy. 1988: A Vértes hegységi Vitány-vár környékének tektonikai elemzése. — A Magyar Állami Földtani Intézet Évi Jelentése 1986-ról, 295-310.

MeIsch, C. 2000: Freshwater Ostracoda of Western and Central Europe. — Spektrum Akademischer Verlag, 522 p.

Murray, J. W. 1973: Distribution and ecology of living benthonic Foraminiferids. - Heinemann, London, 274 p.

ORAVECZ J. \& HAAS J. 1980: Előzetes jelentés a Zsámbék Zs-14. sz. alapfúrás vizsgálatáról. — Kézirat, Magyar Állami Földtani, Geofizikai és Bányászati Adattár, 1.sz.: T1656/29.

PaLotás K. 2014: A szarmata üledékképződés vizsgálata a Budai-hegységben és környékén. — Kézirat, PhD Értekezés, Pécsi Tudományegyetem, Természettudományi Kar

Palotás, K., Selmeczi, I., Szuromi-Korecz, A., Szabados-Sallay, E., BereczKi, L. \& Babinszki, E. 2019: Too salty? Too deep? This is also Sarmatian! (Some new data from the wide range of sedimentary environments in the Central Paratethys, Hungary). — 16th Bathurst Meeting of Carbonate Sedimentologists, Palma de Mallorca 5-12 July 2019. Abstract Volume, Talks, Theme 1: Carbonate Platforms. Carbonate Factories, Depositional Environments, Architecture and Modeling, T-1 to T-9, p. 30.

PARTÉnyi Z., RAdics L. (szerk.), BAKony I., NéMeth A. \& Peregi Zs. 1979: Földtani alapadatok a zsámbéki 1:20 000-es térképlaphoz. — Kézirat, Magyar Állami Földtani, Geofizikai és Bányászati Adattár, Budapest.

RAVASz Cs. 1978: A budajenői kéntartalmú miocén evaporitok ásványkőzettani vizsgálata. — A Magyar Állami Földtani Intézet Évi Jelentése 1976-ról, 177-188.

RAVASZ, Cs. \& Solti, G. 1980: Sulphur-, gypsum- and alginite-bearing strata in the Zsámbék Basin. — Acta Mineralogica-Petrographica 24/2, 191-207.

SASVÁRI, Á. \& BAHAREV, A. 2014: SG2PS (structural geology to post script converter) — A graphical solution for brittle structural data evaluation and paleostress calculation. _ Computers \& Geosciences 66, 81-93 https://doi.org/10.1016/j.cageo.2013.12.010

SELMECZI I. 2008: Középső-miocén. — In: BudAI T. (szerk.): A Gerecse hegység földtana. Magyar Bányászati és Földtani Szolgálat, Budapest, 119-131. 
SElmeCzI I. 2015: Középső-miocén. — In: Kercsmár Zs. (szerk.), Budai T., CsillaG G., SelmeCzi I. \& SzTANó O.: Magyarország felszíni képzódményeinek földtana. Magyarázó Magyarország földtani térképéhez (1:500 000). — Magyar Földtani és Geofizikai Intézet, $35-41$.

Selmeczi I., Szurominé Korecz A., PAlotás K., Szabadosné SAllay E. \& BABinSZKi E. 2018: Óriások lépcsője: egy elfeledett feltárás a Zsámbéki-medencéből. — In: VIRÁG A. \& Bosnakoff M. (szerk.): 21. Magyar Ôslénytani Vándorgyúlés: Program, elöadáskivonatok, kirándulásvezetó. — Budapest, Magyarország: Magyarhoni Földtani Társulat p. 23..

SEMPTEY F. 1943: A Nagykovácsi és Pilisszentiván közt kiemelkedő Szénás-hegycsoport földtani viszonyai. — Földtani Szemle melléklete, $54 \mathrm{p}$.

SzTanó O., Magyar I. \& Csillag G. 2018: Felső-miocén - Pannóniai s.1. — In: Budai T. (szerk.): A Gerecse hegység földtana. Magyar Bányászati és Földtani Szolgálat kiadványa, Budapest, 119-131

Szurominé Korecz A. \& Cserepesné MeszénA B. 2013: Bádeni csökkentsósvízi mikrofauna egy Duna-Tisza közi mélyfúrásból. — 16. Magyar Öslénytani Vándorgyúlés, 2013. május 23-25. Orfú. Program, elóadáskivonatok, kirándulásvezetố, p. 41.

Szuromi-Korecz, A. \& Selmeczi, I. 2015: Middle Miocene evaporates from borehole successions in Hungary. — Neogene of the Paratethyan Region. 6th Workshop on the Neogene of Central and South-eastern Europe. An RCMNS Interim Colloquium, 31 May3 June, Orfü, Hungary. Programme, Abstracts, Field Trip Guidebook, 91-92.

Tо́тн E. 2009: Őskörnyezeti vizsgálatok a Középső-Paratethysben a szarmata folyamán a mikrofauna őslénytani és geokémiai vizsgálata alapján. (Chagements paléoenvironnementaux dans la Paratéthys Centrale pendant le Sarmatien [Miocène moyen]: étude paléontologique de microfaunes et analyses géochimiques.). — Kézirat, PhD Értekezés, ELTE Ôslénytani Tanszék, Université Claude Bernard Lyon 1, Budapest/Lyon, 144 p. + Táblák +Melléklet

Tóth, E., GöröG, Á., Lécuyer, C., Moissette, P., Balter, V. \& Monostori, M. 2009: Palaeoenvironmental reconstruction of the Sarmatian (Middle Miocene) Central Paratethys based on palaeontological and geochemical analyses of foraminifera, ostracods, gastropods and rodents. — Geological Magazine 147/2, 299-314. https://doi.org/10.1017/s0016756809990203

VÉGH S.-né, KovÁCS J. \& MENSÁROS P. 1987: Rátolódás a Csordakút II. bauxitlencse területén. — Földtani Közlöny 117, 93-99.

VÉGH S.-né (szerk.) 1988: A Gerecse előtér kutatásának földtani eredményei. Szerkesztés előtti elsô változat. Az alaphegység kifejlődése, szerkezeti elhelyezkedése a kutatási területen. Az alaphegységhez kötött képződmények. — Kézirat, Magyar Állami Földtani, Geofizikai és Bányászati Adattár, T.15021/5*, 85 p.

Kézirat beérkezett: 2019. 09. 04. 
